\title{
10. COMPOSITION OF HEAVY MINERALS FROM SANDS AND SANDSTONES OF THE IZU-BONIN ARC, LEG $126^{1}$
}

\author{
Kantaro Fujioka ${ }^{2}$ and Saneatsu Saito ${ }^{3}$
}

\begin{abstract}
Lower Oligocene to Pleistocene volcaniclastic sands and sandstones recovered around the Izu-Bonin Arc during Ocean Drilling Program Leg 126 were derived entirely from Izu-Bonin Arc volcanism. Individual grains consist of volcanic glass, pumice, scoria, basaltic or andesitic fragments, plagioclase, pyroxene, and minor olivine and hornblende. In Pliocene-Pleistocene samples plagioclase and heavy minerals in the volcaniclastic sands and sandstones are present in the following abundances: plagioclase $>$ orthopyroxene $>$ clinopyroxene $>$ pigeonite $>$ olivine. In contrast, plagioclase and heavy minerals found in Oligocene-Miocene samples occur in the following order: plagioclase $>$ clinopyroxene $>$ orthopyroxene $>$ hornblende.

The low concentration of $\mathrm{Al}, \mathrm{Ti}$, and $\mathrm{Cr}$ in calcium-rich clinopyroxenes in Oligocene to Holocene sediments suggests that the sources of the volcaniclastic detritus were nonalkalic igneous rocks. There are, however, some distinctive differences in the chemical composition of pyroxene between the Pliocene-Pleistocene and Oligocene-Miocene volcaniclastic sands and sandstones. Orthopyroxene belongs to the hypersthene-ferrohypersthene series (Fe-rich) in Pliocene-Pleistocene sediments, and the bronzitehypersthene series (Mg-rich) in Oligocene-Miocene sediments. Clinopyroxene is characterized by augite and pigeonite in Pliocene-Pleistocene sediments, and by the diopside-augite series in Oligocene-Miocene sediments.

Mineral assemblages and mineral chemistry of the volcaniclastic sands and sandstones reflect those of the volcanic source rocks. Therefore, the observed changes in mineralogy record the historical change in volcanism of the Izu-Bonin Arc. The mineralogy is consistent with the geochemistry of the volcaniclastic sands and sandstones and the geochemistry of forearc volcanic rocks of the Izu-Bonin Arc since the Oligocene.
\end{abstract}

\section{INTRODUCTION}

Clastic rocks, especially sands and sandstones, provide information about the provenance of the sediments (Dickinson, 1974). Volcaniclastic sands and sandstones contain geochemical and mineralogical information relating to the volcanic history of the source area. There have been many studies conducted on volcaniclastic sandstones from active continental margins and backarc basins (Moore, 1979; Klein, 1985; Klein and Lee, 1984), as well as on the processes of submarine volcanic activity (Fisher, 1984; Kokelaar et al., 1985; Carey and Sigurdsson, 1984), but only a few attempts have been made to deduce the volcanic history of island arcs by mineralogical methods (Fujioka and Tsukawaki, in press).

Sands and sandstones that include volcanic fragments and phenocryst minerals often are good indicators of the compositional variation of volcanic rocks over time for several reasons. First, they reflect the original bulk chemistry at the eruption site. Second, phenocryst minerals may indicate the chemical affinity of the source magmas. Third, standard methods in igneous petrology can be applied to the study of the volcanic fragments and minerals. Finally, variations in stratigraphy can closely track changes in chemical characteristics of the volcanic source rocks.

During Ocean Drilling Program (ODP) Leg 126, 19 holes were drilled at 7 sites around the Izu-Bonin Arc, between $30^{\circ}$ and $33^{\circ} \mathrm{N}$ latitude. A major goal of the leg was to reconstruct the volcanic, tectonic, and subsidence/uplift history of the Izu-Bonin intraoceanic margin since the Eocene (Taylor, Fujioka, et al., 1990; Leg 126 Shipboard Scientific Party, 1989) (Fig. 1).

Volcaniclastic materials were recovered from Oligocene sediments at forearc Sites 787, 792, and 793 (Taylor, Fujioka, et al., 1990).

\footnotetext{
${ }^{1}$ Taylor, B., Fujioka, K., et al., 1992. Proc. ODP, Sci. Results, 126: College Station, TX (Ocean Drilling Program).

${ }^{2}$ Ocean Research Institute, University of Tokyo, 1-15-1 Minamidai, Nakano, Tokyo 164. Japan (present address: Japan Marine Science and Technology Center, 2-14 Natsushima, Yokosuka, Kanagowa 238, Japan).

${ }^{3}$ Institute of Geology and Paleontology, Faculty of Science, Tohoku University, Aoba, Sendai 980 , Japan.
}

The provenance of these sandstones includes the nearby forearc basement high (Hiscott and Gill, this volume), which was once subaerial like the present Bonin Islands (Fryer, Pearce, Stokking, et al., 1989). A minimum in volcanic input to the forearc between 24 and 13 Ma corresponds in time with the backarc opening of the Shikoku Basin (Leg 126 Shipboard Scientific Party, 1989). Subsequently, volcanogenic input has increased over the past $13 \mathrm{~m}$.y. Pliocene-Pleistocene volcaniclastic materials were recovered from arc and backarc Sites 788, 790, and 791 (Taylor, Fujioka, et al., 1990).

In this article, we present for the first time, the history of volcanic activity along the middle part of the Izu-Bonin Arc, based upon temporal changes in the petrographic characteristics of the sands and sandstones and the chemical composition of detrital heavy minerals. Other petrographic and geochemical analyses of the same samples of sand and sandstone are presented in other papers (see Hiscott and Gill, this volume; Marsaglia, this volume).

\section{METHODS}

We selected 150 out of 290 Leg 126 samples of sand and sandstone collected jointly by Fujioka et al. (this chapter), Hiscott and Gill (this volume), and Marsaglia (this volume). These samples were used to prepare thin sections: 13 from Site 787, 23 from Site 788, 25 from Site 790, 28 from Site 791, 42 from Site 792, and 17 from Site 793.

Unconsolidated samples were gently crushed and then washed through a $40-\mu \mathrm{m}$ screen and dried. The material was placed in holes on an acrylic plate, flooded with resin, and made into thin sections. If necessary, consolidated samples were impregnated with resin and made directly into thin sections.

After careful examination of the thin sections, 42 were selected for the chemical analysis of the heavy minerals. The selected samples provide a representative chronological record of volcanic characteristics of the Izu-Bonin Arc from the Oligocene to the Pleistocene (Fig. 2).

Chemical analyses of heavy minerals in the sands and sandstones were performed with a Hitachi scanning electron-probe microanalyzer (EPMA, Model X-560S) combined with an energy-dispersive analytical system (EDS), at the Institute of Mineralogy, Petrology and 


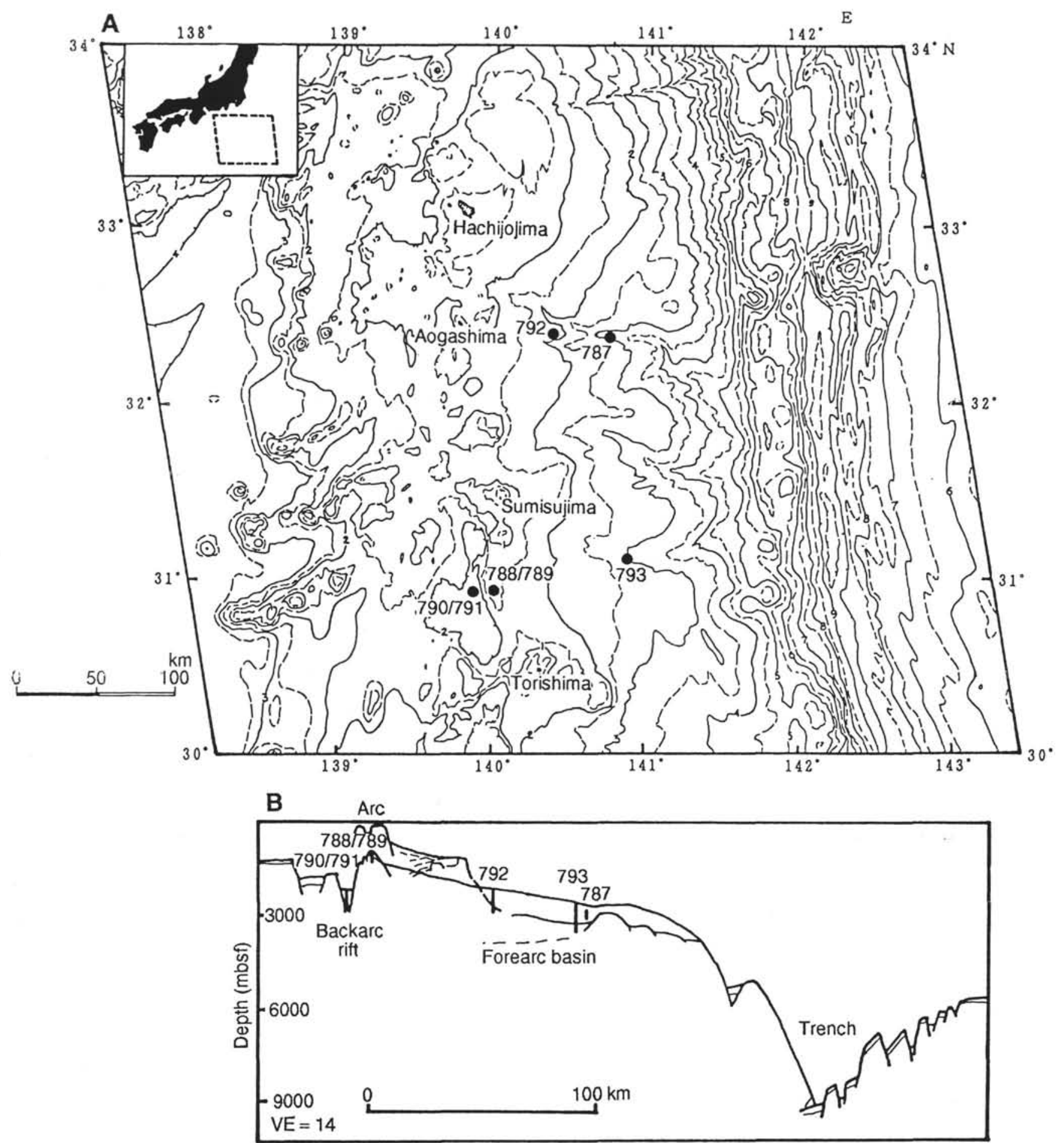

Figure 1. A. Location map of Leg 126 drill sites. Contour intervals in thousands of meters. B. Schematic section of the Izu-Bonin Arc with drill site locations. $\mathrm{VE}=$ vertical exaggeration . 


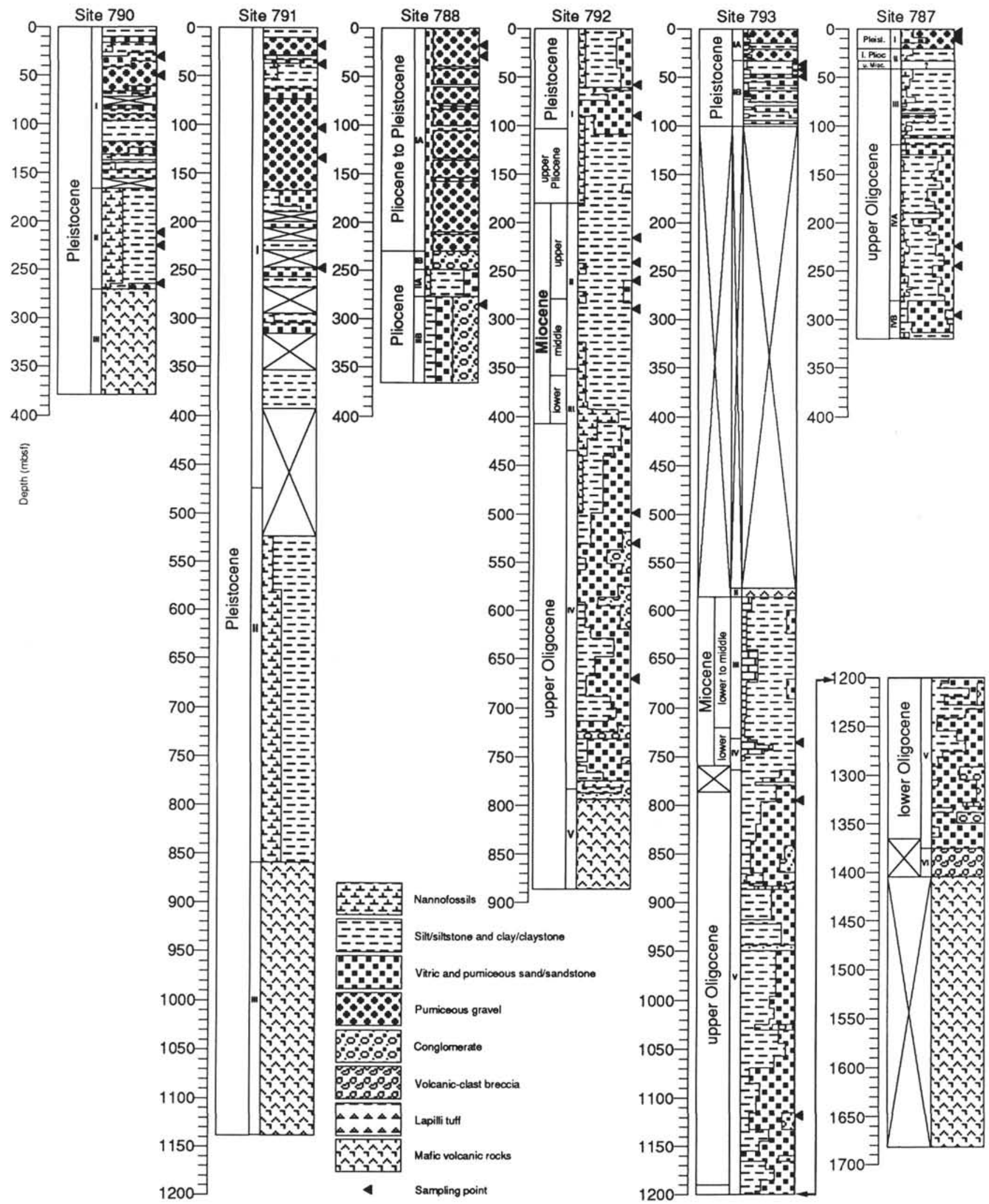

Figure 2. Schematic lithologic columns of the Leg 126 drill sites with the locations of samples on which chemical analyses of heavy minerals were performed. 
Economic Geology, Faculty of Science, Tohoku University, Sendai, Japan. Synthetic and natural mineral standards were used for calibration. Detailed procedures and accuracy of the methods are described in Fujimaki and Aoki (1980).

\section{DESCRIPTION OF SANDS AND SANDSTONES}

\section{Backarc and Island-arc Regions (Sites 790, 791, and 788)}

Sands and sandstones of arc and back-arc regions of the Izu-Bonin Arc (Sites 790, 791, and 788) consist mostly of the following four components: (1) vitric (glassy) components such as translucent volcanic glass, light brown volcanic glass, and pumiceous fragments; (2) lithic fragments such as basaltic rock fragments and scoria; (3) heavy minerals such as pyroxene, olivine, and opaque minerals with plagioclase; and (4) bioclastic material (foraminifers and radiolarians). All the samples observed contain $20 \%-98 \%$ of the vitric component, $5 \%-60 \%$ lithic fragments and $0 \%-45 \%$ heavy minerals plus plagioclase (Fig. 3). Most samples are classified as vitric-lithic-crystal sand/sandstone or vitriclithic sand/sandstone (Cas and Wright, 1987). The crystals are probably phenocrysts from basaltic rocks, as many are attached to a mafic groundmass. The plagioclase content ranges from 50 to $90 \mathrm{vol} \%$ of all the rock-forming minerals in each sample observed. Orthopyroxene and clinopyroxene are common; olivine is rare.

\section{Forearc Region (Sites 787, 792, and 793)}

The unconsolidated sands of the forearc region (Unit I of Sites 787,792 , and 793) have the same petrologic characteristics as the backarc sands, consisting of 5\%-95\% vitric material, $0 \%-85 \%$ lithic material, and $0 \%-45 \%$ crystals and bioclastic material (Fig. 3). However, some samples of the consolidated forearc sandstones (Unit IV of Site 787, Units II-IV of Site 792, and Units V-VII of Site 793), especially lower Oligocene samples, contain diagenetic and alteration minerals such as zeolite, prehnite, and chlorite (Taylor, Fujioka, et al., 1990; Tazaki and Fyfe, this volume).

\section{CHEMICAL ANALYSIS OF HEAVY MINERALS}

A total of 220 analyses were performed on heavy mineral fragments and phenocrysts in basaltic or andesitic rock fragments. We only used analytical data for which the total number of cations were within the limits of $4.00 \pm 0.02$ for pyroxene, and $3.00 \pm 0.02$ for olivine. Analytical results for olivine, augite, pigeonite, orthopyroxene, and hornblende are presented in Tables 1-7; a Ca-Mg-Fe diagram is shown in Figure 4.

\section{Olivine}

Olivine occurs rarely and only in Pleistocene sediments in both backarc (Sites 790 and 791) and forearc areas (Site 787). In the backarc regions, the olivine fragments range in composition from $\mathrm{Fo}_{86}$ to $\mathrm{Fo}_{68}$. The data are presented in Table 1 and shown graphically in Figures $4 \mathrm{E}$ and $4 \mathrm{~F}$. In the forearc regions, two grains of olivine were analyzed in a sample from Unit I at Site 787 (see Table 2 and Fig. 4A). Their composition ranges from $\mathrm{Fo}_{68}$ to $\mathrm{Fo}_{71}$.

\section{Orthopyroxene}

Hypersthene occurs commonly from the Oligocene through the Pleistocene. A little bronzite occurs in the forearc area (Unit I at Site 787, Unit III at Site 787, and Unit II at Site 792). Ferrohypersthene is present only in Pleistocene sediments (Sites 790 and 791 and Unit I at Site 787).

Representative analyses of orthopyroxenes from backarc regions (Holes 788C, 788D, 790B, 790C, and 791A) are given in Table 3 and plotted in Figures 4C, 4E, and 4F. Both hypersthene and ferrohypersthene are found at Sites 790 and 791 . The crystals are markedly zoned and range in composition from $\mathrm{Wo}_{2-5} \mathrm{En}_{42} \mathrm{Fs}_{55}$ to $\mathrm{Wo}_{2-5} \mathrm{En}_{63} \mathrm{Fs}_{35}$.

Representative analyses of orthopyroxenes from forearc regions (Holes 787A, 787B, and 792B) are given in Table 4 and plotted in Figures $4 \mathrm{~A}, 4 \mathrm{~B}$, and $4 \mathrm{G}-4 \mathrm{~L}$. The crystals in the upper Pliocene to

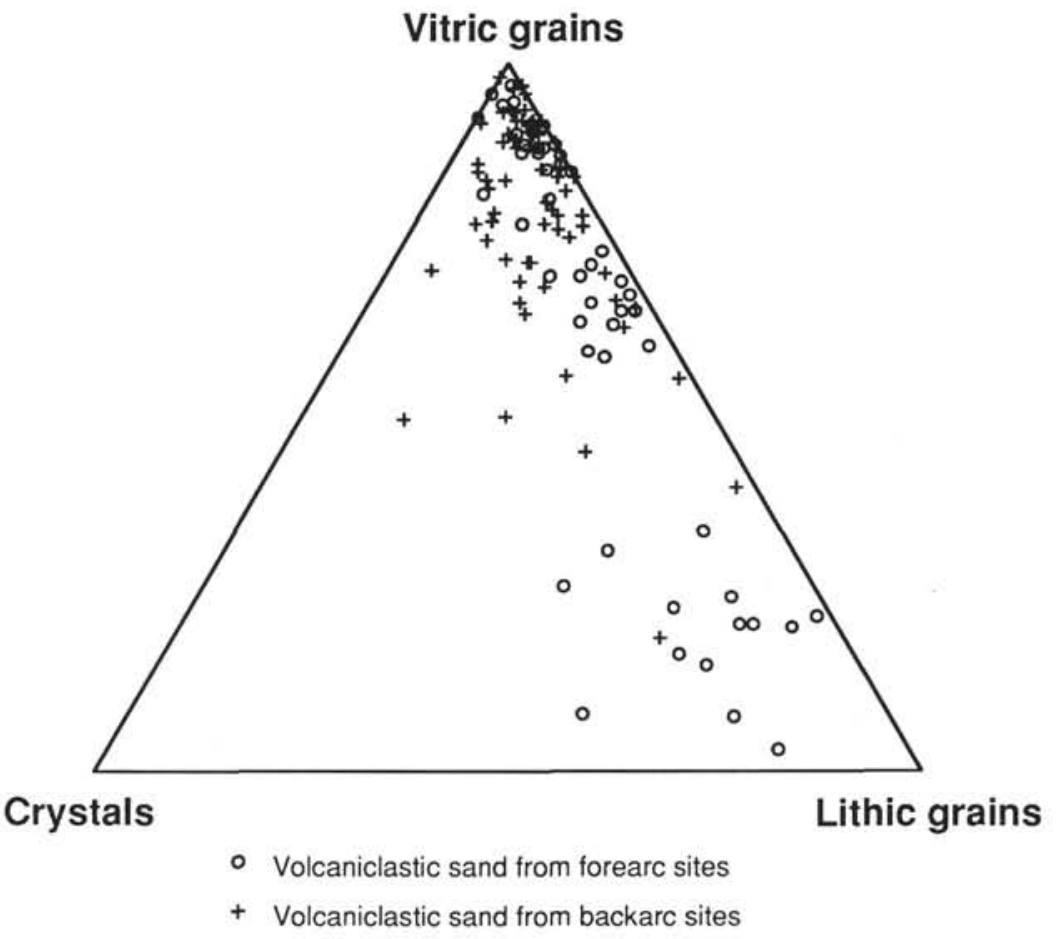

Figure 3. Vitric-crystal-lithic diagram of the volcaniclastic materials from Leg 126 sites. 


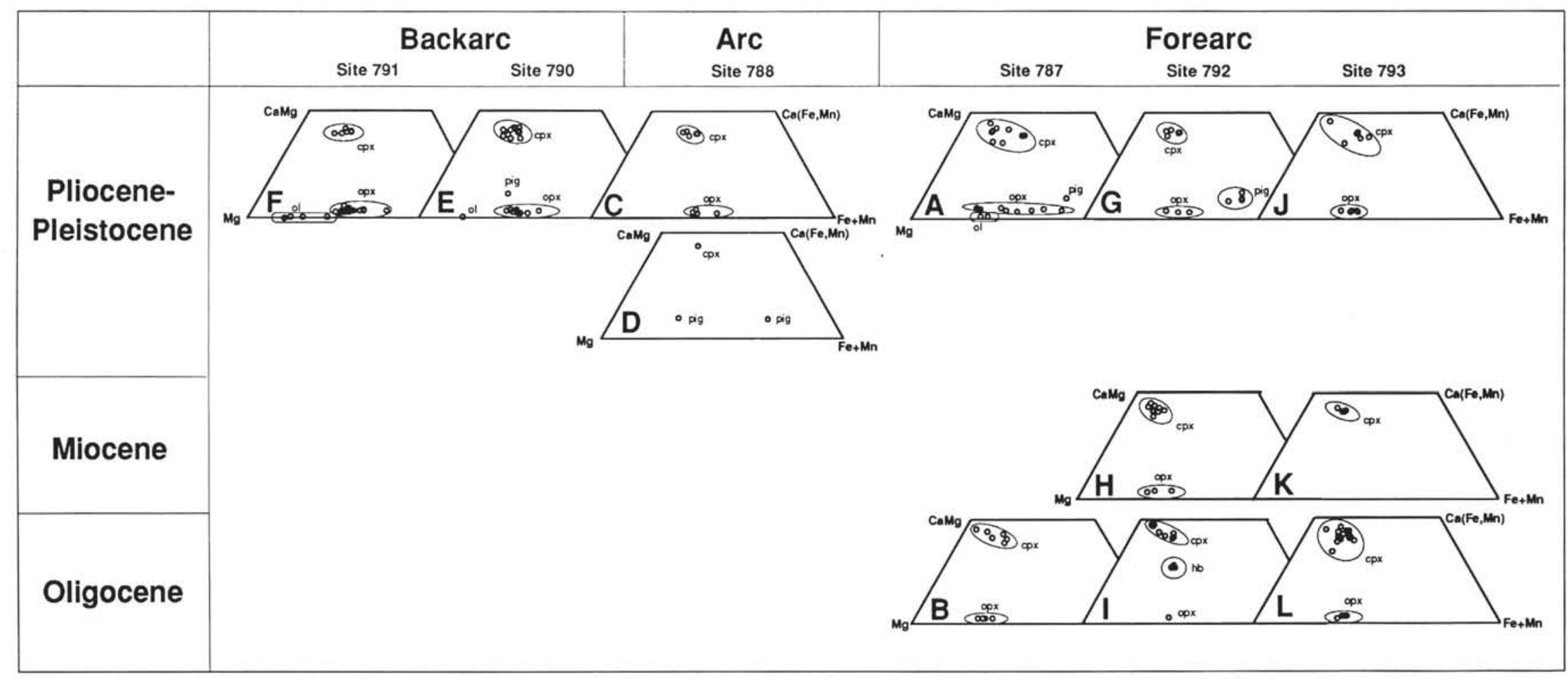

Figure 4. Ca-Mg-Fe diagrams for detrital heavy minerals. A. Cores 126-787B-1R to -3R. B. Section 126-787B-14R-1, 135 cm, to Core 126-787B-30R. C. Core 126-788A-4H and Cores 126-788C-1H to -24H. D. Cores 126-788D-7R, $8 \mathrm{~cm}$, to -16R. E. Cores 126-790A-1H to -4H, Cores 126-790B-1H to -15H, and Core 126-790C-1H to Section 126-790C-20X-CC, $34 \mathrm{~cm}$. F. Cores 126-791A-1H to -46X and Core 126-791B-IR to Section 126-791B-47R-1, $44 \mathrm{~cm}$. G. Cores 126-792A-1H to -10H, Cores 126-792B-1H to - 11H, Core 126-792C-1H, Core 126-792D-1X, and Cores 126-792E-1X to -5R. H. Core 126-792E-32R to Section 126-792E-68R-2, $100 \mathrm{~cm}$. I. Core 126-792E-6R to Section 126-792E-24R-1, $10 \mathrm{~cm}$. J. Cores 126-793A-5H to -11H. K. Core 126-793B-2R to Section 126-793B-16R-5, 0 cm. L. Section 126-793B-19R-1, $60 \mathrm{~cm}$, to Core 126-793B-114R. 
Table 1. Representative analyses of olivines in backarc samples.

\begin{tabular}{|c|c|c|c|c|c|}
\hline $\begin{array}{l}\text { Hole } \\
\text { Core, section } \\
\text { Interval (cm) } \\
\text { Grain }\end{array}$ & $\begin{array}{c}790 \mathrm{~B} \\
5 \mathrm{H}-1 \\
113-116 \\
\mathrm{OL}-1\end{array}$ & $\begin{array}{l}791 \mathrm{~A} \\
5 \mathrm{H}-2 \\
92-95 \\
\mathrm{OL}-1\end{array}$ & $\begin{array}{l}791 \mathrm{~A} \\
5 \mathrm{H}-2 \\
92-95 \\
\mathrm{OL}-2\end{array}$ & $\begin{array}{c}791 \mathrm{~A} \\
28 \mathrm{X}-\mathrm{CC} \\
8-11 \\
\mathrm{OL}-1\end{array}$ & $\begin{array}{c}791 \mathrm{~A} \\
28 \mathrm{X}-\mathrm{CC} \\
8-11 \\
\mathrm{OL}-2\end{array}$ \\
\hline \multicolumn{6}{|c|}{ Major elements (wt\%): } \\
\hline $\mathrm{SiO}_{2}$ & 39.52 & 38.93 & 37.24 & 39.77 & 39.47 \\
\hline $\mathrm{FeO}^{-}$ & 16.62 & 19.91 & 27.79 & 13.42 & 15.51 \\
\hline $\mathrm{MnO}$ & 0.30 & 0.34 & 0.53 & 0.20 & 0.27 \\
\hline $\mathrm{MgO}$ & 43.08 & 40.52 & 33.81 & 45.39 & 44.37 \\
\hline $\mathrm{CaO}$ & 0.29 & 0.23 & 0.23 & 0.21 & 0.23 \\
\hline Total & 99.80 & 99.94 & 99.60 & 98.98 & 99.85 \\
\hline Cations & $\mathrm{O}=4$ & & & & \\
\hline \multicolumn{6}{|c|}{ Trace elements (ppm): } \\
\hline $\mathrm{Si}$ & 0.002 & 1.002 & 1.001 & 1.002 & 0.996 \\
\hline $\mathrm{Fe}$ & 0.353 & 0.429 & 0.625 & 0.283 & 0.327 \\
\hline Mn & 0.006 & 0.007 & 0.012 & 0.004 & 0.006 \\
\hline $\mathrm{Mg}$ & 1.628 & 1.554 & 1.355 & 1.704 & 1.669 \\
\hline $\mathrm{Ca}$ & 0.008 & 0.006 & 0.007 & 0.006 & 0.006 \\
\hline Total & 2.998 & 2.998 & 2.999 & 2.998 & 3.004 \\
\hline
\end{tabular}

Pleistocene sands range in composition from $\mathrm{Wo}_{3-5} \mathrm{En}_{36-71} \mathrm{Fs}_{25-60}$. The orthopyroxenes in the Miocene and Oligocene sandstones have a more limited compositional range of $\mathrm{Wo}_{3-4} \mathrm{En}_{58-69} \mathrm{Fs}_{28-37}$ for the Miocene samples and $\mathrm{Wo}_{2-4} \mathrm{En}_{61-71} \mathrm{Fs}_{26-36}$ for the Oligocene samples. Most of the orthopyroxenes are grouped in the hypersthene field; ferrohypersthene was identified only in Unit I at Site 787, whereas bronzite was identified in Unit I and Subunit IVA at Site 787 and Unit II at Site 792.

\section{Pigeonite}

A few crystals of pigeonite occur only in Pleistocene sediments (Sites 787, 788, 790, 791, and 792). In the backarc and island-arc regions, pigeonite crystals were identified in the samples from Sites 790 and 788. Their compositions are $\mathrm{Wo}_{9} \mathrm{En}_{63} \mathrm{Fs}_{27}, \mathrm{Wo}_{9} \mathrm{En}_{26} \mathrm{Fs}_{64}$, and $\mathrm{Wo}_{12} \mathrm{En}_{57} \mathrm{Fs}_{31}$ (see Table 3 and Fig. 4D-E).

In the forearc regions, only the upper Pliocene to Pleistocene sands contain pigeonite, with a composition of $\mathrm{Wo}_{9-12} \mathrm{En}_{29-37} \mathrm{Fs}_{55-60}$ (see Table 4 and Figs. 4A and 4G).

\section{Augite and Diopside}

Augite occurs commonly from the Oligocene through the Pleistocene, especially in Oligocene to Miocene sediments. Augite generally constitutes more than $50 \%$ of the total heavy minerals. Diopside occurs commonly from the Oligocene through the Miocene in the forearc region and is present only rarely in Pliocene-Pleistocene sediments of Unit I at Site 793.

Representative analyses of calcium-rich pyroxene from the backarc and island-arc regions (Holes 788C, 788D, 790B, 790C, and 791B) are given in Table 5 and are illustrated graphically in Figures $4 \mathrm{C}-4 \mathrm{~F}$. The augite pheno-crysts have a limited compositional range with low abundances of $\mathrm{Mg}\left(\mathrm{Wo}_{38-43} \mathrm{En}_{37-46} \mathrm{Fs}_{14-22}\right), \mathrm{Ti}\left(<0.51 \mathrm{wt} \% \mathrm{TiO}_{2}\right)$, and $\mathrm{Al}(<3.46$ $w t \% \mathrm{Al}_{2} \mathrm{O}_{3}$ ).

Representative analyses of abundant augite crystals from forearc regions are given in Table 6 and plotted in Figures 4A and 4G-4L. Upper Pliocene to Pleistocene sands (Unit I at Site 787, Unit I at Site 792 , and Unit I at Site 793) have a composition of $\mathrm{Wo}_{35-46} \mathrm{En}_{34-49} \mathrm{Fs}_{6-27}$. Miocene sandstones (Unit II at Site 792 and Unit III at Site 793) and Oligocene sandstones (Subunit IVA of Site 787, Unit IV of Site 792 and Units IV, V, and VI of Site 793) show ranges of $\mathrm{Wo}_{39-46} \mathrm{En}_{41-49} \mathrm{Fs}_{8-16}$ and $\mathrm{Wo}_{39-47} \mathrm{En}_{41-52} \mathrm{Fs}_{8-16}$, respectively. Several grains of diopside were identified in Oligocene sandstones (six grains), Miocene sandstones (two grains), and Pleistocene sands (one grain).

\section{Hornblende}

A few crystals of hornblende occur only in Oligocene sediment. Hornblende was observed in only one thin section (Sample 126-792E-
$56 \mathrm{R}-5,33-36 \mathrm{~cm}$ ), where it is more abundant than pyroxene. Representative analyses of hornblende are given in Table 7 and shown graphically in Figure 4I.

\section{DISCUSSION}

\section{Characterization of Volcanic Rock Series}

Petrological and geochemical characteristics of volcanic rocks may be directly related to their tectonic settings (Jakes and White, 1972; Miyashiro, 1974). However, post-emplacement alteration tends to obscure the original mineralogical and geochemical characteristics of the volcanic rocks and thus the reconstructions of paleotectonic regions.

Volcaniclastic sands and sandstones are a monogenetic derivative of volcanic rocks and preserve the original geochemical characteristics of the source rocks. However, it is often difficult to determine the chemistry of the original volcanic rocks from the analysis of secondary sediments (Hiscott and Gill, this volume), because the sediments are variable mixtures of volcanic glass, pumice, scoria, rock-forming minerals, lithic fragments, and biogenic clasts. Detrital clinopyroxene phenocrysts, therefore, are a more reliable indicator of source-rock chemistry.

Kushiro (1960) discussed the chemical composition of pyroxenes, especially the $\mathrm{Si}, \mathrm{Al}$, and $\mathrm{Ti}$ contents in relation to the magma series. Leterrier et al. (1982) proposed a method of identification for the magmatic affinities of a paleovolcanic series based on the unaltered clinopyroxene compositions of 706 Holocene-age volcanic rocks. Three major basaltic groups can be distinguished with confidence $>80 \%$ : alkali-basalt and related rocks, tholeiite from spreading centers, and orogenic basalt, respectively (Fig. 5). In spite of metamorphic or metasomatic processes, the primary chemical composition of relict clinopyroxene phenocrysts is commonly preserved.

Figures $5 \mathrm{~A}$ and $5 \mathrm{~B}$ show that clinopyroxenes from alkali basalt differ from the other groups in their generally higher contents of $\mathrm{Ca}, \mathrm{Ti}$, and total $\mathrm{Al}$, and Figure 5C shows the distinction between clinopyroxenes from alkali basalt (rich in $\mathrm{Ti}$ and $\mathrm{Na}$ ) and the other groups (Leterrier et al., 1982). All our data from clinopyroxenes in Oligocene to Pleistocene sands and sandstones plot in the nonalkali basalt field (Fig. 5).

None of the discriminating diagrams clearly separate clinopyroxenes of orogenic basalt from those of oceanic tholeiites. Based on low- $\mathrm{Cr}$ contents, however, the detrital clinopyroxenes must have come from the orogenic basalts, either island-arc tholeiites, or calc alkalic basalts in continental margins (Leterrier et al., 1982). This result suggests that sedimentary basins around the Izu-Bonin Arc received reworked island-arc tholeiitic detritus since the Oligocene, in agreement with the results of Hiscott and Gill (this volume).

\section{Volcanic History of the Izu-Bonin Arc from the Oligocene to the Pleistocene}

Backarc and forearc stratigraphy records the history of variations in intensity and chemistry of Izu-Bonin Arc volcanism. Abundances of heavy minerals in these sediments vary temporally and spatially (Fig. 6). In particular, the assemblage of the heavy minerals differs markedly between Pliocene-Pleistocene and Oligocene-Miocene volcaniclastic sands and sandstones. This change in heavy mineral composition represents a change in character of the petrology of the Izu-Bonin Arc through time. The Oligocene-Miocene volcanic source was characterized by a mineral assemblage including plagioclase, augite, hypersthene, diopside, bronzite, and hornblende, from the tholeiitic or calc-alkalic volcanic rock series. These volcanic rocks are similar to the basement lavas and breccias recovered at Sites 792 and 793 (Taylor et al., this volume; Lapierre et al., this volume). The source rocks for Pliocene-Pleistocene volcaniclastic sands are characterized by a mineral assemblage that includes plagioclase, hypersthene, augite, ferrohypersthene, pigeonite, and olivine from the tholeiitic volcanic rock series. Volcanic rocks of this type have been produced at the volcanic front of the Izu-Bonin Arc since about $3 \mathrm{Ma}$ (Fujioka, Taylor, et al., 1989). 
A
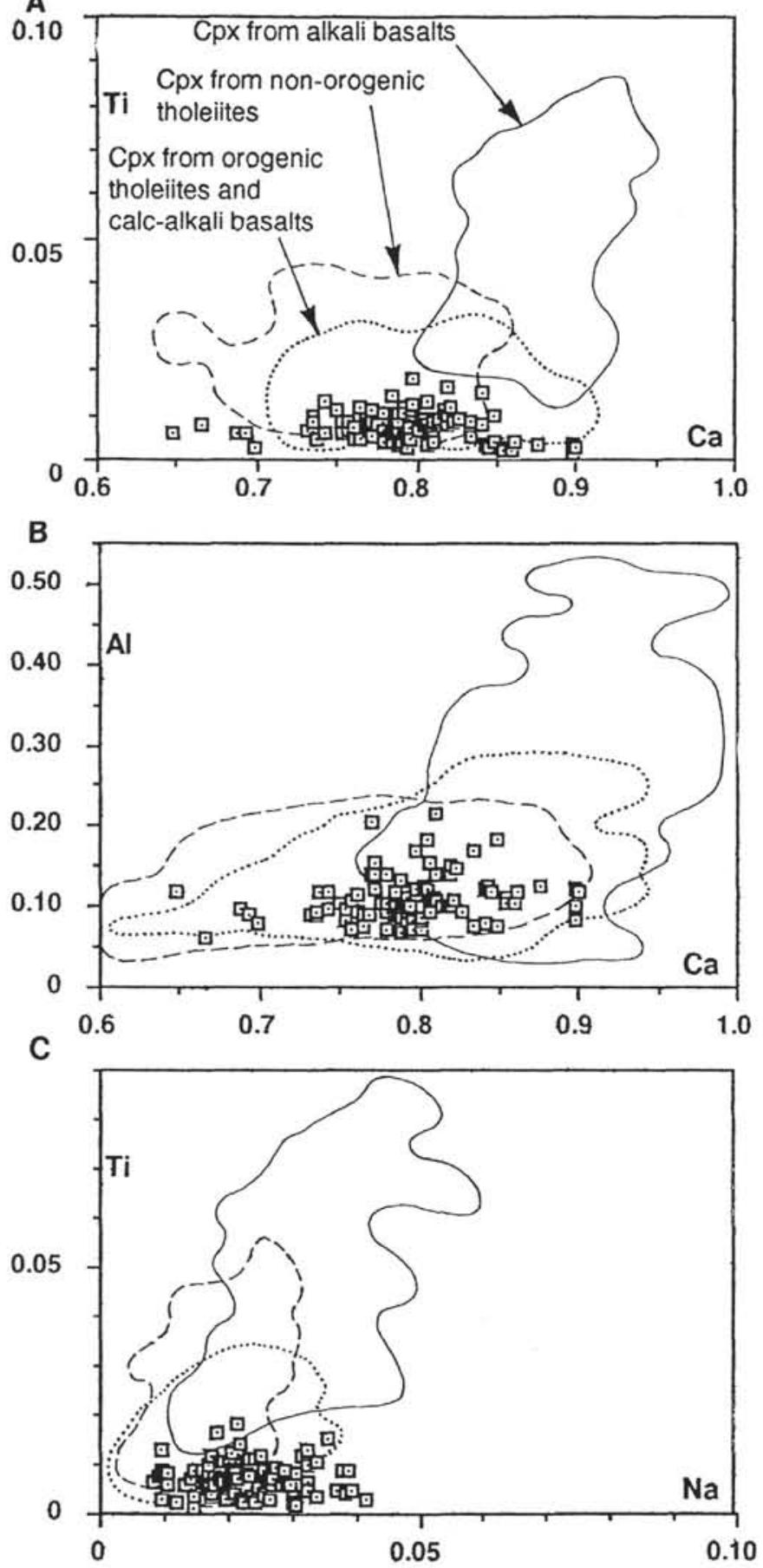

Figure 5. The distribution of the compositions of clinopyroxene phenocrysts for three principal basaltic families: alkali and related basalts, nonorogenic tholeiitic basalts, and orogenic tholeiitic and calc-alkaline basalts. The distribution of each family is defined by computer-drawn frequency curves (after Leterrier et al., 1982). Chemical compositions of clinopyroxenes in sandstones from the Leg 126 sites are superimposed. The elements are calculated as cationic values from the structural formula of the clinopyroxene.

\section{CONCLUSIONS}

Volcaniclastic sands and sandstones recovered from Leg 126 drilling around the Izu-Bonin Arc are composed of volcanic glass, pumice, scoria, basaltic or andesitic rock fragments, plagioclase, heavy minerals, and biogenic clasts.
In Pliocene-Pleistocene sands the mineral abundances are as follows: plagioclase $>$ orthopyroxene $>$ clinopyroxene $>$ pigeonite $>$ olivine. In Oligocene-Miocene sandstones the mineral abundances are different and are present in the following order: plagioclase $>$ clinopyroxene $>$ orthopyroxene $>$ hornblende.

Calcium-rich detrital clinopyroxene is characterized by low abundances of $\mathrm{Al}, \mathrm{Ti}$, and $\mathrm{Cr}$. This indicates that the source volcanic rocks from the Oligocene to the Present were nonalkalic igneous rocks.

There is a distinct difference in the magnesium-iron and calcium contents of pyroxenes in the Pliocene-Pleistocene vs. those in Oligocene-Miocene volcaniclastic sandstone. Orthopyroxene belongs to the hypersthene-ferrohypersthene series in Pliocene-Pleistocene sediments, and to the bronzite-hypersthene series in Oligocene-Miocene sediments. Clinopyroxene is characterized by augite and pigeonite in Pliocene-Pleistocene sediments, and the diopside-augite series in Oligocene-Miocene sediments.

The mineralogical characteristics of the volcaniclastic sands and sandstones reflect the volcanic history of the Izu-Bonin Arc. Conclusions based on mineralogy are quite consistent with stratigraphic inferences by geochemistry of volcaniclastic sands and sandstones (Hiscott and Gill, this volume), with mineralogical inferences by geochemistry of forearc volcanic rocks (Lapierre et al., this volume), and with the other inferences related to the history of volcanism of the Izu-Bonin Arc since the Oligocene (Fujioka et al., this volume).

\section{ACKNOWLEDGMENTS}

Discussions with Drs. R. Hiscott, K. Marsaglia, A. Nishimura, and K. Rodolfo, onboard sedimentologists on Leg 126, helped us to prepare this chapter. We would like to express our sincere thanks to them and to Dr. T. Hasenaka of the Institute of Mineralogy, Petrology, and Economic Geology, Faculty of Science, Tohoku University for EPMA analysis of heavy minerals and for his valuable suggestions. Mr. M. Shishido made thin sections for the analyses. We thank Drs. H. Nakagawa and K. Ishizaki of the Institute of Geology and Paleontology, Faculty of Science, Tohoku University; Dr. M. Yuasa, Geological Survey of Japan; and Dr. H. Okada, Kyushu University, for critically reading the manuscript.

\section{REFERENCES}

Carey, S., and Sigurdsson, H., 1984. A model of volcanogenic sedimentation in marginal basins. In Kokelaar, B. P., and Howells, M. F. (Eds.), Margin Basin Geology. Geol. Soc. London, 37-58.

Cas, R.A.F. and Wright, J. V., 1987. Volcanic Successions: Modern and Ancient: London (Allen and Unwin).

Dickinson, W. R. (Ed.), 1974. Tectonics and Sedimentation. Spec. Publ., Soc. Econ. Paleontol. Mineral., 22:1-27.

Fisher, R. V., 1984. Submarine volcaniclastic rocks. In Kokelaar, B. P., and Howells, M. F. (Eds.), Marginal Basin Geology: Volcanic and Associated Sedimentary Processes in Modern and Ancient Basins. Spec. Publ., Geol. Soc. London, 16:5-28.

Fryer, P., Pearce, J. A., Stokking, L. B., et al., 1989. Proc. ODP, Init. Repts., 125: College Station, TX (Ocean Drilling Program).

Fujimaki, H., and Aoki, K., 1980. Quantitative micro-analyses of silicate, oxides and sulfides using an energy-dispersive type electron probe. Sci. Rep. Tohoku Univ., Ser. 3, 14:261-268.

Fujioka, K., Taylor, B., Nishimura, A., Koyama, M., Kaiho, K., Tazaki, K., Janecek, T., and Scientific Party of Leg 126, 1989. Drilling across the Izu-Bonin Arc: results of ODP Leg 126 cruise. J. Geography, 98:54-78. (In Japanese)

Fujioka, K., and Tsukawaki, S., in press. Fate of volcaniclastic materials along volcanic front: a model for accretion in So-o trough between northern Izu-Bonin Arc and southern Boso Peninsula. J. Volcanol. Soc. Jpn.

Jakes, P., and White, A.J.R., 1972. Major and trace element abundances in volcanic rocks of orogenic areas. Geol. Soc. Am. Bull., 83:29-40.

Klein, G. deV., 1985. The control of depositional depth, tectonic uplift, and volcanism on sedimentation processes in the back-arc basins of the western Pacific Ocean. J. Geol., 93:1-25.

Klein, G. deV., and Lee, Y., 1984. A preliminary assessment of geodynamic controls on depositional systems and sandstone diagenesis in back-arc basins, western Pacific Ocean. Tectonophysics, 102:119-52. 
Table 2. Representative analyses of olivines in forearc samples.

\begin{tabular}{|c|c|c|c|c|c|c|c|c|c|c|c|c|c|}
\hline $\begin{array}{l}\text { Hole } \\
\text { Core, section } \\
\text { Interval (cm) } \\
\text { Grain }\end{array}$ & $\begin{array}{l}788 \mathrm{C} \\
3 \mathrm{H}-1 \\
42-46 \\
\text { OPX-1 }\end{array}$ & $\begin{array}{l}788 \mathrm{C} \\
3 \mathrm{H}-1 \\
42-46 \\
\text { OPX-2 }\end{array}$ & $\begin{array}{l}788 \mathrm{C} \\
4 \mathrm{H}-1 \\
64-67 \\
\text { OPX-2 }\end{array}$ & $\begin{array}{l}788 \mathrm{C} \\
4 \mathrm{H}-1 \\
64-67 \\
\text { OPX-3 }\end{array}$ & $\begin{array}{l}788 \mathrm{D} \\
8 \mathrm{R}-1 \\
29-32 \\
\text { CPX-7 }\end{array}$ & $\begin{array}{c}788 \mathrm{D} \\
8 \mathrm{R}-1 \\
29-32 \\
\text { CPX-8 }\end{array}$ & $\begin{array}{c}790 \mathrm{~B} \\
5 \mathrm{H}-1 \\
113-116 \\
\text { OPX-1 }\end{array}$ & $\begin{array}{c}790 \mathrm{~B} \\
5 \mathrm{H}-1 \\
113-118 \\
\mathrm{OPX}-2\end{array}$ & $\begin{array}{c}790 \mathrm{~B} \\
5 \mathrm{H}-1 \\
113-116 \\
\mathrm{OPX}-3\end{array}$ & $\begin{array}{c}790 \mathrm{~B} \\
6 \mathrm{H}-4 \\
16-20 \\
\text { OPX-1 }\end{array}$ & $\begin{array}{c}790 \mathrm{~B} \\
6 \mathrm{H}-4 \\
16-20 \\
\text { OPX-2 }\end{array}$ & $\begin{array}{c}790 \mathrm{C} \\
15 \mathrm{X}-\mathrm{CC} \\
12-14 \\
\mathrm{CPX}-1\end{array}$ & $\begin{array}{c}790 \mathrm{C} \\
15 \mathrm{X}-\mathrm{CC} \\
12-14 \\
\text { CPX-1 }\end{array}$ \\
\hline \multicolumn{14}{|c|}{ Major elements (wt\%): } \\
\hline $\mathrm{SiO}_{2}$ & 51.77 & 52.40 & 52.72 & & & 49.14 & & 52.72 & 52.43 & 52.46 & 52.66 & 52.83 & 51.88 \\
\hline $\mathrm{TiO}_{2}$ & 0.29 & 0.14 & 0.22 & 0.12 & 0.14 & 0.10 & 0.17 & 0.19 & 0.18 & 0.17 & 0.15 & 0.20 & 0.12 \\
\hline $\mathrm{Al}_{2} \mathrm{O}_{3}$ & 1.66 & 0.64 & 1.23 & 0.72 & 1.78 & 0.62 & 1.04 & 1.26 & 1.38 & 0.92 & 0.83 & 1.19 & 0.83 \\
\hline $\mathrm{FeO}$ & 22.69 & 23.71 & 22.27 & 27.28 & 16.80 & 35.70 & 22.02 & 21.12 & 21.12 & 22.89 & 22.27 & 19.00 & 25.75 \\
\hline $\mathrm{MnO}$ & 1.89 & 1.95 & 1.85 & $\begin{array}{r}2.58 \\
2.54\end{array}$ & $\begin{array}{r}10.80 \\
0.41\end{array}$ & 1.45 & $\begin{array}{l}22.02 \\
1.40\end{array}$ & 0.84 & $\begin{array}{r}21.12 \\
0.81\end{array}$ & 1.53 & 1.45 & 0.47 & 1.32 \\
\hline $\mathrm{MgO}$ & 19.49 & 19.75 & 20.04 & 16.66 & 22.27 & 8.53 & 20.90 & 21.91 & 21.77 & 20.42 & 21.13 & 20.26 & 18.71 \\
\hline $\mathrm{CaO}$ & 2.33 & 1.41 & 1.63 & 1.38 & 4.92 & 4.22 & 1.42 & 1.72 & 1.70 & 1.46 & 1.46 & 5.60 & 1.25 \\
\hline $\begin{array}{l}\mathrm{Na}_{2} \mathrm{O} \\
\text { Total }\end{array}$ & 100.12 & 100.00 & 99.96 & 100.01 & $\begin{array}{r}0.47 \\
100.60\end{array}$ & 99.76 & $\begin{array}{r}0.30 \\
99.87\end{array}$ & $\begin{array}{r}0.26 \\
100.02\end{array}$ & 99.39 & 99.84 & 99.95 & $\begin{array}{r}0.10 \\
99.54\end{array}$ & 99.87 \\
\hline Cations & $\mathrm{O}=4$ & & & & & & & & & & & & \\
\hline \multirow{2}{*}{\multicolumn{14}{|c|}{ Trace elements (ppm): }} \\
\hline & 1.953 & 1.983 & 1.980 & 1.981 & 1.968 & 1.994 & 1.975 & 1.964 & 1.964 & 1.977 & 1.976 & 1.972 & 1.979 \\
\hline $\mathrm{Ti}$ & 0.008 & 0.004 & 0.006 & 0.003 & 0.004 & 0.003 & 0.005 & 0.005 & 0.0 & 0.005 & 0.0 & 0.006 & 0.004 \\
\hline $\mathrm{Al}$ & 0.074 & 0.029 & 0.0 & 0.034 & 0.077 & 0.030 & 0.046 & 0.055 & 0.061 & 0.041 & 0.037 & 0.053 & 0.037 \\
\hline $\mathrm{Fe}$ & 0.716 & 0.750 & 0.700 & 0.881 & 0.513 & 1.212 & 0.691 & 0.658 & 0.662 & 0.721 & 0.699 & 0.594 & 0.821 \\
\hline Mn & 0.060 & 0.063 & 0.059 & 0.083 & 0.013 & 0.050 & 0.044 & 0.026 & 0.026 & 0.049 & 0.046 & 0.015 & 0.043 \\
\hline $\mathrm{Mg}$ & 1.096 & 1.114 & 1.122 & 0.959 & 1.212 & 0.516 & 1.169 & 1.216 & 1.215 & 1.147 & 1.182 & $\begin{array}{l}1.129 \\
\end{array}$ & 1.064 \\
\hline $\mathrm{Ca}$ & 0.094 & 0.057 & 0.065 & 0.057 & 0.193 & 0.183 & 0.057 & 0.069 & 0.068 & 0.059 & 0.059 & 0.224 & 0.051 \\
\hline $\mathrm{Na}$ & & & & & 0.033 & & 0.022 & 0.018 & & & & 0.007 & \\
\hline Total & 4.002 & 3.999 & 3.986 & 3.999 & 4.010 & 3.988 & 4.008 & 4.012 & 4.001 & 3.998 & 4.002 & 4.000 & 3.999 \\
\hline
\end{tabular}

Table 2 (continued).

\begin{tabular}{|c|c|c|c|c|c|c|c|c|c|c|c|c|c|c|}
\hline $\begin{array}{l}\text { Hole } \\
\text { Core, section } \\
\text { Interval (cm) } \\
\text { Grain }\end{array}$ & $\begin{array}{c}790 \mathrm{C} \\
15 \mathrm{X}-\mathrm{CC} \\
12-14 \\
\text { OPX-2 }\end{array}$ & $\begin{array}{c}790 \mathrm{C} \\
15 \mathrm{X}-\mathrm{CC} \\
12-14 \\
\text { OPX-3 }\end{array}$ & $\begin{array}{c}790 \mathrm{C} \\
15 \mathrm{X}-\mathrm{CC} \\
12-14 \\
\text { OPX-4 }\end{array}$ & $\begin{array}{l}790 \mathrm{C} \\
16 \mathrm{X}-5 \\
66-69 \\
\text { OPX-1 }\end{array}$ & $\begin{array}{l}790 \mathrm{C} \\
16 \mathrm{X}-5 \\
66-69 \\
\text { OPX-2 }\end{array}$ & $\begin{array}{l}790 \mathrm{C} \\
20 \mathrm{X}-5 \\
31-34 \\
\text { OPX-1 }\end{array}$ & $\begin{array}{l}791 \mathrm{~A} \\
3 \mathrm{H}-1 \\
63-66 \\
\text { OPX-1 }\end{array}$ & $\begin{array}{l}791 \mathrm{~A} \\
3 \mathrm{H}-1 \\
83-86 \\
\text { OPX-2 }\end{array}$ & $\begin{array}{l}791 \mathrm{~A} \\
3 \mathrm{H}-1 \\
83-86 \\
\text { OPX-3 }\end{array}$ & $\begin{array}{l}791 \mathrm{~A} \\
3 \mathrm{H}-1 \\
83-86 \\
\text { OPX-4 }\end{array}$ & $\begin{array}{l}791 \mathrm{~A} \\
3 \mathrm{H}-1 \\
83-86 \\
\text { OPX-5 }\end{array}$ & $\begin{array}{l}791 \mathrm{~A} \\
5 \mathrm{H}-2 \\
92-95 \\
\text { OPX-1 }\end{array}$ & $\begin{array}{l}791 \mathrm{~A} \\
5 \mathrm{H}-2 \\
92-95 \\
\text { OPX-2 }\end{array}$ & $\begin{array}{l}791 \mathrm{~A} \\
5 \mathrm{H}-2 \\
92-95 \\
\text { OPX-3 }\end{array}$ \\
\hline \multicolumn{15}{|c|}{ Major elements (wt\%): } \\
\hline $\mathrm{SiO}_{2}$ & 52.40 & 52.80 & 52.38 & 52.32 & 51.38 & 52.95 & 52.67 & 52.38 & 52.47 & 51.49 & 51.25 & 52.91 & 52.30 & 52.40 \\
\hline $\mathrm{TiO}_{2}$ & 0.31 & $\begin{array}{l}0.08 \\
0.72\end{array}$ & 0.23 & 0.20 & $\begin{array}{l}0.20 \\
0.89\end{array}$ & 0.10 & 0.19 & 0.21 & $\begin{array}{l}0.16 \\
0.82\end{array}$ & 0.18 & 0.20 & 0.28 & 0.15 & $\begin{array}{l}0.19 \\
109\end{array}$ \\
\hline $\mathrm{Al}_{2} \mathrm{O}_{3}$ & $\begin{array}{l}1.14 \\
22.76\end{array}$ & $\begin{array}{r}0.72 \\
23.96\end{array}$ & 1.07 & 1.29 & 0.89 & 0.57 & 1.07 & 1.21 & 0.82 & 1.02 & $\begin{array}{r}0.90 \\
25.73\end{array}$ & & 0.90 & $\begin{array}{r}1.09 \\
0357\end{array}$ \\
\hline $\begin{array}{l}\mathrm{FeO} \\
\mathrm{MnO}\end{array}$ & $\begin{array}{r}22.76 \\
0.70\end{array}$ & $\begin{array}{l}23.96 \\
1.33\end{array}$ & $\begin{array}{r}23.53 \\
0.80\end{array}$ & 23.15 & 27.56 & $\begin{array}{r}23.35 \\
1.63\end{array}$ & 22.97 & 24.43 & 23.41 & 26.54 & 25.73 & 22.79 & 24.73 & 23.57 \\
\hline $\mathrm{MgO}$ & 2.124 & $\begin{array}{r}1.33 \\
1957\end{array}$ & $\begin{array}{r}0.80 \\
20.05\end{array}$ & 0.98 & $\begin{array}{r}1.69 \\
16.94\end{array}$ & 2.63 & 0.85 & 0.70 & 1.45 & 0.92 & $\begin{array}{l}1.17 \\
1872\end{array}$ & 1.10 & 1.01 & 1.25 \\
\hline $\mathrm{CaO}$ & 21.24 & 1.21 & 20.05 & 20.1 & $\begin{array}{r}16.94 \\
1.58\end{array}$ & $\begin{array}{l}20.31 \\
1.22\end{array}$ & 20.3 & 19.85 & 19.7 & 17. & 18.23 & 20.8 & 19.36 & 20.16 \\
\hline $\mathrm{Na}_{2} \mathrm{O}$ & & & 1.00 & 1.89 & & & 1.86 & 1.71 & 1.7 & 1.8 & 1.64 & 2.1 & 1.55 & 1.53 \\
\hline Total & 100.64 & 99.67 & 99.88 & 99.96 & 100.24 & 100.13 & 99.95 & 100.48 & 99.84 & 99.69 & 99.13 & 100.67 & 100.01 & 100.21 \\
\hline Cations & $\mathrm{O}=4$ & & & & & & & & & & & & & \\
\hline \multicolumn{15}{|c|}{ Trace elements $(\mathrm{ppm})$ : } \\
\hline $\mathrm{Si}$ & 1.955 & 1.997 & 1.974 & 1.969 & 1.975 & 1.991 & 1.978 & 1.968 & 1.983 & 1.97 & 1.973 & 1.981 & 1.980 & 1.971 \\
\hline $\mathrm{Ti}$ & 0.009 & 0.002 & 0.0 & 0.006 & 0.006 & 0.003 & 0.0 & 0.0 & 0.0 & 0.0 & 0.006 & 0.006 & 0.004 & 0.005 \\
\hline $\mathrm{Al}$ & 0.050 & 0.032 & 0.048 & 0.057 & 0.404 & 0.025 & 0.047 & 0.053 & 0.036 & 0.048 & 0.041 & & 0.040 & 0.048 \\
\hline $\mathrm{Fe}$ & 0.710 & 0.758 & 0.742 & 0.729 & 0.886 & 0.734 & 0.721 & 0.768 & 0.740 & 0.852 & 0.828 & 0.714 & 0.783 & 0.742 \\
\hline Mn & 0.022 & 0.043 & 0.025 & 0.031 & 0.055 & 0.052 & 0.027 & 0.022 & 0.047 & 0.029 & 0.038 & 0.035 & 0.033 & 0.040 \\
\hline & $\begin{array}{l}1.181 \\
\text { lo }\end{array}$ & 1.104 & $\begin{array}{l}.126 \\
1.12\end{array}$ & 1.129 & 0.971 & $\begin{array}{l}0.138 \\
\end{array}$ & 1.139 & 1.112 & 1.113 & 1.012 & $\begin{array}{l}.046 \\
\end{array}$ & 1.162 & 1.092 & $\begin{array}{l}1.131 \\
\text { S }\end{array}$ \\
\hline $\mathrm{Ca}$ & 0.084 & 0.049 & 0.074 & 0.076 & 0.065 & 0.049 & 0.075 & 0.069 & 0.072 & 0.077 & 0.068 & 0.111 & 0.063 & 0.063 \\
\hline $\begin{array}{l}\text { Na } \\
\text { Total }\end{array}$ & 4.011 & 3.985 & 3.995 & 3.997 & 3.999 & 3.993 & 3.993 & 3.999 & 3.995 & 3.995 & 4.001 & 4.011 & 3.993 & 3.999 \\
\hline
\end{tabular}

Kokelaar, B. P., Bevins, R. E., and Roach, R. A., 1985. Submarine silicic volcanism and associated sedimentary and tectonic processes, Ramsey Islands, SW Wales. J. Geol. Soc. London, 142:591-613.

Kushiro, I., 1960. Si-Al relation in clinopyroxenes from igneous rocks. Am. J. Sci., 258:548-554.

Leg 126 Shipboard Scientific Party, 1989. Arc volcanism and rifting. Nature, 342:18-20.

Leterrier, J., Maury, R. C., Thonon, P., Girard, D., and Marchal, M., 1982. Clinopyroxene composition as a method of identification of the magmatic affinities of paleo-volcanic series. Earth Planet. Sci. Lett., 59:139-154.
Miyashiro, A., 1974. Volcanic rock series in island arcs and active continental margins. Am. J. Sci., 274:321-355.

Moore, G. F., 1979. Petrology of subduction zone sandstones from Nias Island, Indonesia. J. Sediment. Petrol., 49:71-84.

Taylor, B., Fujioka, K., et al., 1990. Proc. ODP, Init. Rept., 126: College Station, TX (Ocean Drilling Program).

Date of initial receipt: 4 December 1990

Date of acceptance: 17 May 1991

Ms 126B-125 
Table 2 (continued).

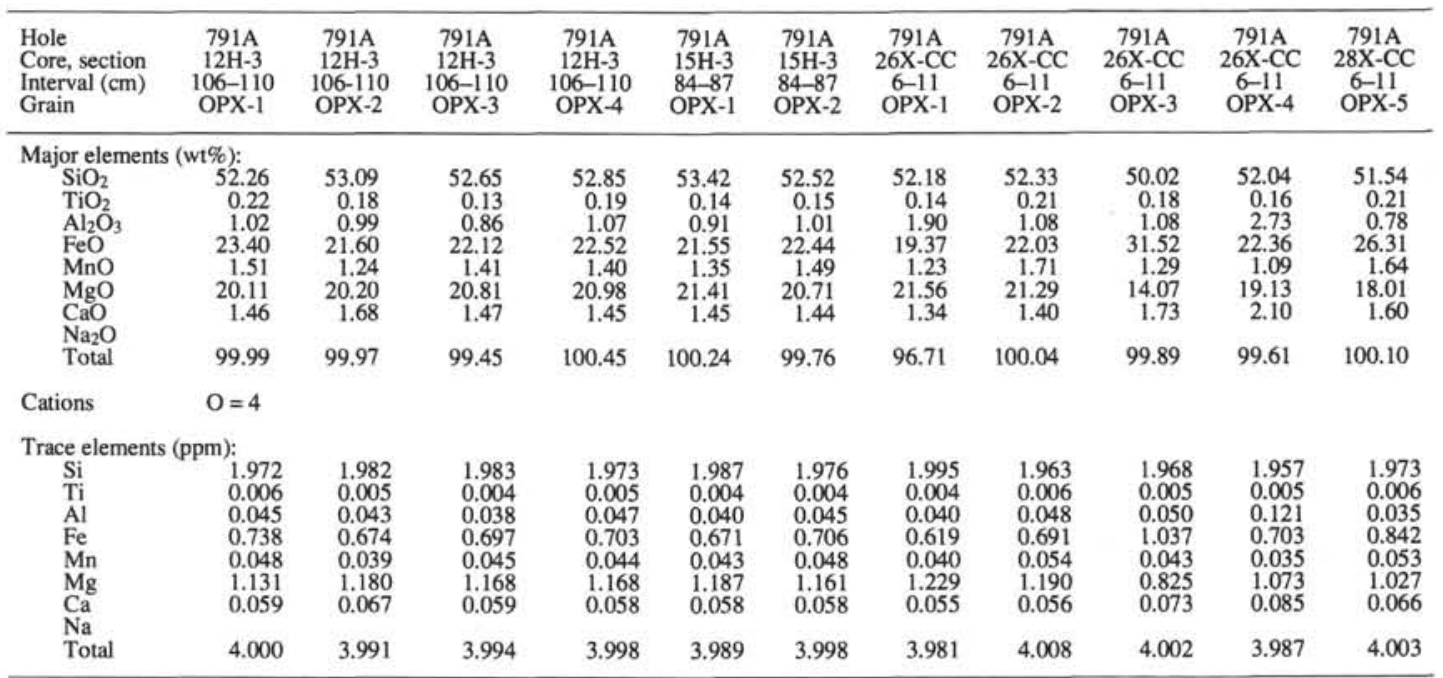

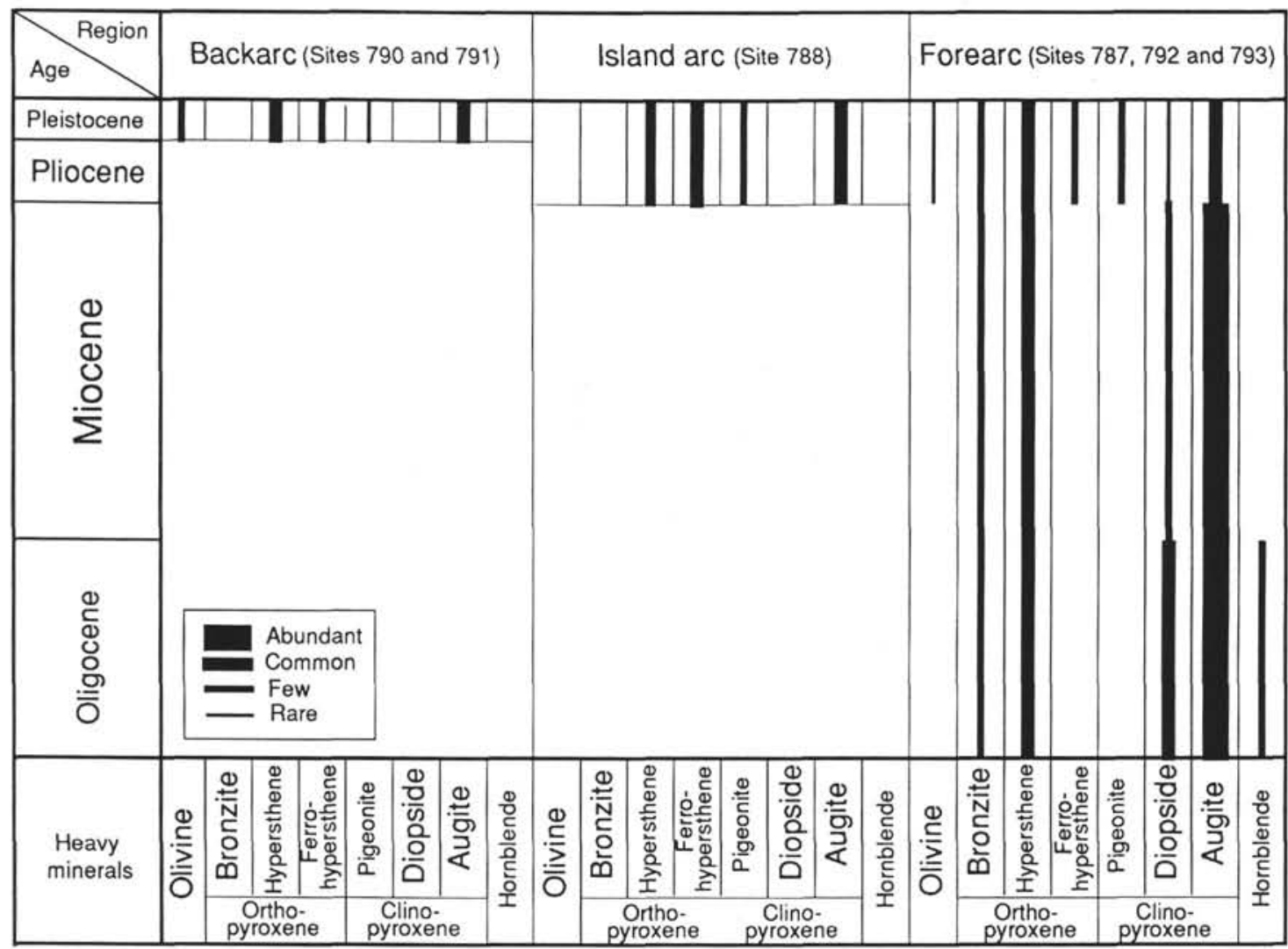

Figure 6. Temporal variation of heavy minerals in the sands and sandstones from the Leg 126 sites. 
Table 3. Representative analyses of Ca-poor pyroxenes in backarc samples.

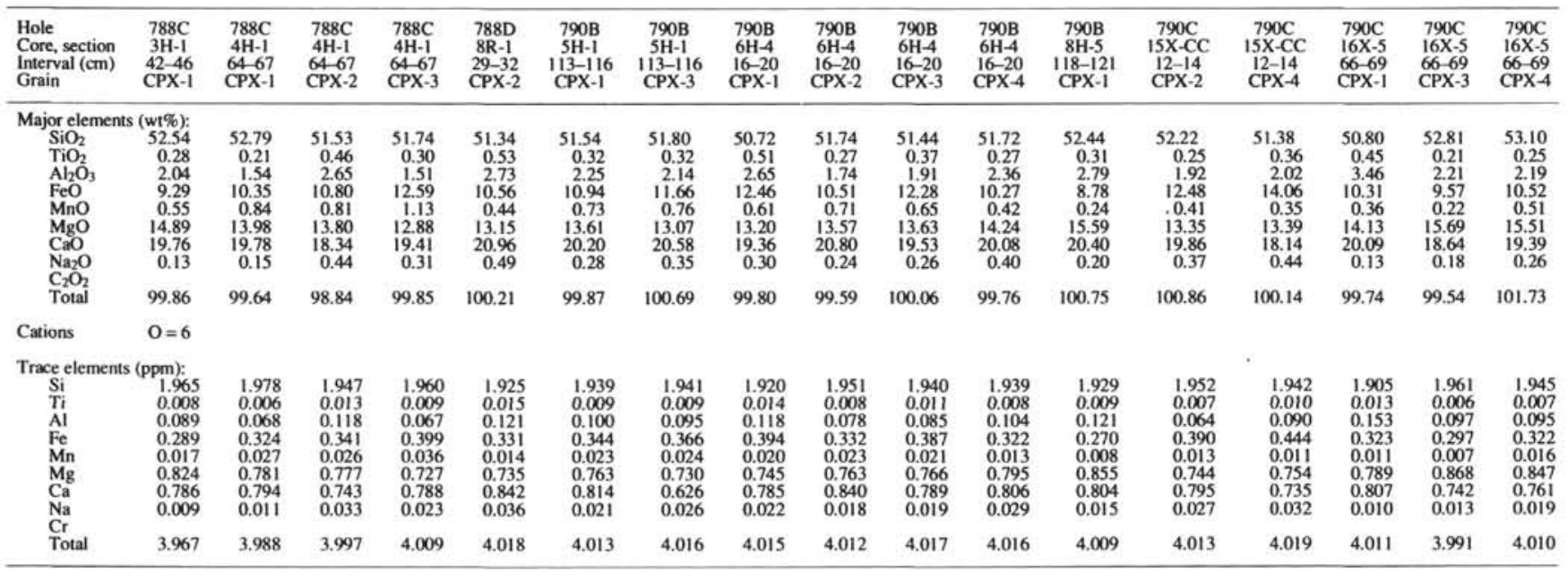

Table 3 (continued).

\begin{tabular}{|c|c|c|c|c|c|c|c|c|c|c|}
\hline $\begin{array}{l}\text { Hole } \\
\text { Core, section } \\
\text { Interval (cm) } \\
\text { Grain }\end{array}$ & $\begin{array}{l}790 \mathrm{C} \\
16 \mathrm{X}-5 \\
66-69 \\
\text { CPX-1 }\end{array}$ & $\begin{array}{l}790 \mathrm{C} \\
16 \mathrm{X}-5 \\
66-69 \\
\text { CPX-3 }\end{array}$ & $\begin{array}{l}790 \mathrm{C} \\
16 \mathrm{X}-5 \\
66-69 \\
\text { CPX-4 }\end{array}$ & $\begin{array}{l}790 \mathrm{C} \\
16 X-5 \\
66-69 \\
\text { CPX-5 }\end{array}$ & $\begin{array}{l}791 \mathrm{~A} \\
3 \mathrm{H}-1 \\
83-86 \\
\text { CPX-1 }\end{array}$ & $\begin{array}{l}791 \mathrm{~A} \\
3 \mathrm{H}-1 \\
83-86 \\
\text { CPX-2 }\end{array}$ & $\begin{array}{l}791 \mathrm{~A} \\
5 \mathrm{H}-2 \\
92-95 \\
\mathrm{CPX}-2\end{array}$ & $\begin{array}{l}791 \mathrm{~A} \\
5 \mathrm{H}-6 \\
53-56 \\
\text { CPX-1 }\end{array}$ & $\begin{array}{c}791 \mathrm{~A} \\
12 \mathrm{H}-3 \\
106-110 \\
\text { CPX-2 }\end{array}$ & $\begin{array}{l}791 \mathrm{~B} \\
44 \mathrm{R}-1 \\
22-24 \\
\text { CPX-2 }\end{array}$ \\
\hline \multicolumn{11}{|c|}{ Major elements (w1\%): } \\
\hline $\mathrm{SiO}_{2}$ & 50.80 & 52.81 & 53.10 & 52.09 & 51.79 & 51.22 & 52.12 & 51.70 & 51.87 & 51.74 \\
\hline $\mathrm{TiO}_{2}$ & 0.45 & 0.21 & 0.25 & 0.24 & 0.24 & 0.41 & 0.32 & 0.26 & 0.17 & 0.38 \\
\hline $\mathrm{Al}_{2} \mathrm{O}_{3}$ & 3.46 & 2.21 & 2.19 & 2.04 & 3.21 & 2.47 & 2.08 & 1.59 & 1.63 & 1.83 \\
\hline $\mathrm{FeO}$ & 10.31 & 9.57 & 10.52 & 11.56 & 9.13 & 10.80 & 10.95 & 12.56 & 12.28 & 11.49 \\
\hline $\mathrm{MnO}$ & 0.36 & 0.22 & 0.51 & 0.36 & 0.20 & 0.62 & 0.37 & 0.60 & 0.90 & 0.72 \\
\hline $\mathrm{MgO}$ & 14.13 & 15.69 & 15.51 & 15.13 & 15.63 & 13.43 & 14.70 & 13.05 & 13.10 & 13.73 \\
\hline $\mathrm{CaO}$ & 20.09 & 18.64 & 19.39 & 18.28 & 19.36 & 20.30 & 19.19 & 19.58 & 19.21 & 19.63 \\
\hline $\begin{array}{l}\mathrm{Na}_{2} \mathrm{O} \\
\mathrm{C}_{2} \mathrm{O}_{2}\end{array}$ & 0.13 & 0.18 & 0.26 & 0.45 & 0.11 & 0.43 & 0.35 & 0.22 & 0.50 & 0.26 \\
\hline Total & 99.74 & 99.54 & 101.73 & 100.14 & 99.68 & 99.68 & 100.08 & 99.55 & 99.67 & 99.81 \\
\hline \multicolumn{11}{|l|}{ Cations } \\
\hline \multicolumn{11}{|c|}{ Trace elements (ppm): } \\
\hline $\mathrm{Si}$ & 1.905 & 1.961 & 1.945 & 1.945 & 1.923 & 1.931 & 1.946 & 1.960 & 1.963 & 1.949 \\
\hline Ti & 0.013 & 0.006 & 0.007 & 0.007 & 0.007 & 0.012 & 0.009 & 0.008 & 0.005 & 0.011 \\
\hline Al & 0.153 & 0.097 & 0.095 & 0.09 & 0.140 & 0.110 & 0.092 & 0.071 & 0.073 & 0.081 \\
\hline $\mathrm{Fe}$ & 0.323 & 0.297 & 0.322 & 0.361 & 0.284 & 0.341 & 0.342 & 0.398 & 0.3 & 0.362 \\
\hline Mn & 0.011 & 0.007 & 0.016 & 0.011 & 0.006 & 0.020 & 0.012 & 0.019 & 0.029 & 0.023 \\
\hline $\mathrm{Mg}$ & 0.789 & 0.868 & 0.847 & 0.842 & 0.865 & 0.755 & 0.818 & 0.737 & 0.739 & 0.711 \\
\hline $\mathrm{Ca}$ & 0.807 & 0.742 & 0.761 & 0.732 & 0.770 & 0.820 & 0.768 & 0.795 & 0.779 & 0.792 \\
\hline $\mathrm{Na}$ & 0.010 & 0.013 & 0.019 & 0.032 & 0.008 & 0.032 & 0.025 & 0.016 & 0.037 & 0.020 \\
\hline Total & 4.011 & 3.991 & 4.010 & 4.020 & 4.004 & 4.019 & 4.012 & 4.005 & 4.014 & 4.010 \\
\hline
\end{tabular}

Table 4. Representative analyses of Ca-poor pyroxenes in forearc samples.

\begin{tabular}{|c|c|c|}
\hline $\begin{array}{l}\text { Hole } \\
\text { Core, section } \\
\text { Interval }(\mathrm{cm}) \\
\text { Grain }\end{array}$ & $\begin{array}{l}787 \mathrm{~B} \\
2 \mathrm{R}-1 \\
6-10 \\
\mathrm{OL}-1\end{array}$ & $\begin{array}{l}787 \mathrm{~B} \\
2 \mathrm{R}-1 \\
6-10 \\
\text { OL-2 }\end{array}$ \\
\hline \multicolumn{3}{|c|}{ Major elements (wt\%): } \\
\hline $\mathrm{SiO}_{2}$ & 37.58 & 37.80 \\
\hline $\mathrm{FeO}$ & 27.99 & 25.22 \\
\hline $\mathrm{MnO}$ & 0.52 & 0.44 \\
\hline $\mathrm{MgO}$ & 34.14 & 36.46 \\
\hline $\mathrm{CaO}$ & 0.21 & 0.21 \\
\hline Total & 100.44 & 100.14 \\
\hline \multicolumn{3}{|c|}{ Cations $\mathrm{O}=4$} \\
\hline \multicolumn{3}{|c|}{ Trace elements (ppm): } \\
\hline $\mathrm{Si}$ & 1.001 & 0.997 \\
\hline $\mathrm{Fe}$ & 0.624 & 0.556 \\
\hline Mn & 0.012 & 0.010 \\
\hline $\mathrm{Mg}$ & 1.356 & 1.433 \\
\hline $\mathrm{Ca}$ & 0.006 & 0.006 \\
\hline Total & 2.999 & 3.003 \\
\hline
\end{tabular}


Table 5. Representative analyses of Ca-rich pyroxenes in backarc samples.

\begin{tabular}{|c|c|c|c|c|c|c|c|c|c|c|c|c|c|c|c|c|}
\hline $\begin{array}{l}\text { Hole } \\
\text { Core, section } \\
\text { Interval (cm) } \\
\text { Grain }\end{array}$ & $\begin{array}{l}787 \mathrm{~A} \\
1 \mathrm{~W}-3 \\
15-21 \\
\text { OPX-1 }\end{array}$ & $\begin{array}{l}787 \mathrm{~A} \\
1 \mathrm{~W}-3 \\
15-21 \\
\text { OPX-2 }\end{array}$ & $\begin{array}{l}787 \mathrm{~A} \\
1 \mathrm{~W}-3 \\
15-21 \\
\text { OPX-3 }\end{array}$ & $\begin{array}{l}787 \mathrm{~A} \\
1 \mathrm{~W}-3 \\
15-21 \\
\text { OPX-4 }\end{array}$ & $\begin{array}{l}787 \mathrm{~B} \\
\text { IR-1 } \\
48-52 \\
\text { OPX-1 }\end{array}$ & $\begin{array}{c}787 \mathrm{~B} \\
\text { IR-1 } \\
48-52 \\
\text { OPX-2 }\end{array}$ & $\begin{array}{c}787 \mathrm{~B} \\
2 \mathrm{R}-1 \\
103-107 \\
\text { OPX-1 }\end{array}$ & $\begin{array}{c}787 \mathrm{~B} \\
2 \mathrm{R}-1 \\
6-11 \\
\text { OPX-1 }\end{array}$ & $\begin{array}{l}787 \mathrm{~B} \\
2 \mathrm{R}-1 \\
6-11 \\
\text { OPX-1 }\end{array}$ & $\begin{array}{c}787 \mathrm{~B} \\
2 \mathrm{R}-1 \\
6-11 \\
\text { OPX-2 }\end{array}$ & $\begin{array}{l}787 \mathrm{~B} \\
24 \mathrm{R}-6 \\
91-94 \\
\text { OPX-1 }\end{array}$ & $\begin{array}{l}787 \mathrm{~B} \\
27 \mathrm{R}-1 \\
77-80 \\
\text { OPX-1 }\end{array}$ & $\begin{array}{l}787 \mathrm{~B} \\
32 \mathrm{R}-1 \\
54-56 \\
\text { OPX-1 }\end{array}$ & $\begin{array}{l}787 \mathrm{~B} \\
32 \mathrm{R}-1 \\
54-56 \\
\text { OPX-2 }\end{array}$ & $\begin{array}{c}792 \mathrm{~B} \\
2 \mathrm{H}-3 \\
145-148 \\
\text { OPX-1 }\end{array}$ & $\begin{array}{c}792 \mathrm{~B} \\
2 \mathrm{H}-3 \\
145-148 \\
\text { OPX-1 }\end{array}$ \\
\hline \multicolumn{17}{|c|}{ Major elements (wt\%): } \\
\hline $\mathrm{SiO}_{2}$ & 53.85 & 53.78 & 52.39 & 53.99 & 51.90 & 51.04 & 50.56 & 49.43 & 49.82 & 51.95 & 53.54 & 53.96 & 53.81 & 53.16 & 50.43 & 51.59 \\
\hline $\mathrm{TiO}_{2}$ & 0.15 & 0.15 & 0.24 & 0.14 & 0.20 & 0.13 & 0.14 & 0.17 & 0.16 & 0.20 & 0.17 & 0.05 & 0.12 & 0.19 & 0.16 & 0.34 \\
\hline $\mathrm{Al}_{2} \mathrm{O}_{3}$ & 1.55 & 2.09 & 1.63 & 1.98 & 0.99 & 0.97 & 0.67 & 0.63 & 0.58 & 1.53 & 2.22 & 1.48 & 1.54 & 3.09 & 0.66 & 1.76 \\
\hline $\mathrm{FeO}$ & 16.21 & 16.61 & 21.36 & 15.54 & 25.03 & 28.60 & 30.57 & 33.73 & 34.51 & 22.50 & 17.97 & 19.37 & 17.43 & 16.16 & 31.04 & 24.70 \\
\hline $\mathrm{MnO}$ & 0.38 & 0.38 & 0.59 & 0.37 & 1.06 & 1.15 & 1.10 & 1.58 & 1.55 & 0.87 & 0.53 & 0.83 & 0.58 & 0.45 & 1.63 & 1.05 \\
\hline $\mathrm{MgO}$ & 25.90 & 24.86 & 21.41 & 25.52 & 19.11 & 16.43 & 14.79 & 10.52 & 12.10 & 20.72 & 24.08 & 22.73 & 24.94 & 25.53 & 12.37 & 19.12 \\
\hline${ }_{\mathrm{Na}}^{\mathrm{CaO}}$ & 1.99 & 2.07 & 2.16 & 2.35 & 1.50 & 1.64 & 1.81 & $\begin{array}{r}4.19 \\
0\end{array}$ & 1.73 & 1.82 & 1.56 & 1.52 & 1.58 & 1.41 & 3.98 & 1.75 \\
\hline Total & 99.43 & 99.94 & 99.77 & 99.90 & 99.80 & 99.95 & 99.65 & 100.38 & 100.44 & 99.60 & 100.07 & 99.93 & 100.01 & 100.00 & $\begin{array}{r}0.00 \\
100.34\end{array}$ & 100.31 \\
\hline Cations & $0=6$ & & & & & & & & & & & & & & & \\
\hline \multicolumn{17}{|c|}{ Trace elements (ppm): } \\
\hline $\mathrm{Si}$ & 1.966 & 1.956 & 1.957 & 1.957 & 1.974 & 1.974 & 1.983 & 1.976 & 1.980 & 1.957 & 1.955 & 1.986 & 1.963 & 1.927 & 1.986 & 1.950 \\
\hline $\mathrm{Ti}$ & 0.004 & 0.004 & 0.007 & 0.004 & 0.0 & 0.004 & 0.0 & 0.005 & 0.0 & 0.0 & & & & & 0.005 & 0.010 \\
\hline $\mathrm{Al}$ & 0.067 & 0.090 & 0.072 & 0.085 & 0.04 & 0.044 & 0.0 & 0.030 & 0.0 & 0.068 & 0.0 & 0.064 & 0.0 & 0.1 & 0.031 & 0.079 \\
\hline $\mathrm{Fe}$ & 0.495 & 0.505 & 0.677 & 0.471 & 0.796 & 0.925 & 1.003 & 1.128 & 1.147 & 0.709 & 0.549 & 0.596 & 0.532 & 0.490 & 1.022 & 0.781 \\
\hline Mn & 0.012 & 0.012 & 0.019 & 0.012 & 0.034 & 0.038 & 0.037 & 0.054 & 0.052 & 0.028 & 0.016 & 0.026 & 0.018 & 0.014 & 0.054 & 0.034 \\
\hline $\mathrm{Mg}$ & 1.376 & 1.348 & 1.192 & 1.379 & 1.083 & 0.947 & 0.864 & 0.627 & 0.717 & 1.163 & 1.311 & 1.247 & 1.356 & 1.3 & 0.726 & 1.078 \\
\hline $\mathrm{Ca}$ & 0.078 & 0.081 & 0.086 & 0.091 & 0.061 & 0.068 & 0.076 & 0.180 & 0.074 & 0.074 & 0.061 & 0.060 & 0.062 & 0.055 & 0.168 & 0.071 \\
\hline $\begin{array}{l}\mathrm{Na} \\
\text { Total }\end{array}$ & 3.997 & 3.995 & 4.000 & 3.997 & 3.998 & 4.000 & 3.998 & $\begin{array}{l}0.009 \\
4.008\end{array}$ & 4.002 & 4.004 & 3.992 & 3.981 & 4.000 & 4.002 & $\begin{array}{l}0.005 \\
3.997\end{array}$ & 4.001 \\
\hline
\end{tabular}

Table 5 (continued).

\begin{tabular}{|c|c|c|c|c|c|c|c|c|c|c|c|c|c|c|c|c|}
\hline $\begin{array}{l}\text { Hole } \\
\text { Core, section } \\
\text { Interval (cm) } \\
\text { Grain }\end{array}$ & $\begin{array}{c}792 \mathrm{~B} \\
2 \mathrm{H}-3 \\
145-148 \\
\mathrm{OPX}-2\end{array}$ & $\begin{array}{c}792 \mathrm{E} \\
9 \mathrm{R}-5 \\
26-31 \\
\text { OPX-1 }\end{array}$ & $\begin{array}{c}792 \mathrm{E} \\
9 \mathrm{R}-5 \\
26-31 \\
\text { OPX-1 }\end{array}$ & $\begin{array}{l}792 \mathrm{E} \\
16 \mathrm{R}-2 \\
93-97 \\
\text { OPX-1 }\end{array}$ & $\begin{array}{l}792 \mathrm{E} \\
38 \mathrm{R}-5 \\
50-54 \\
\text { OPX-1 }\end{array}$ & $\begin{array}{l}792 \mathrm{E} \\
16 \mathrm{R}-2 \\
93-97 \\
\text { OPX-2 }\end{array}$ & $\begin{array}{l}793 \mathrm{~A} \\
6 \mathrm{H}-3 \\
44-48 \\
\text { OPX-2 }\end{array}$ & $\begin{array}{l}793 \mathrm{~A} \\
6 \mathrm{H}-3 \\
44-48 \\
\text { OPX-3 }\end{array}$ & $\begin{array}{l}793 \mathrm{~A} \\
7 \mathrm{H}-1 \\
94-98 \\
\text { OPX-1 }\end{array}$ & $\begin{array}{c}793 \mathrm{~A} \\
9 \mathrm{H}-2 \\
111-114 \\
\text { OPX-1 }\end{array}$ & $\begin{array}{c}793 \mathrm{~A} \\
9 \mathrm{H}-2 \\
111-114 \\
\text { OPX-2 }\end{array}$ & $\begin{array}{l}\text { 793B } \\
22 \mathrm{R}-3 \\
33-36 \\
\text { OPX-1 }\end{array}$ & $\begin{array}{l}793 \mathrm{~B} \\
22 \mathrm{R}-3 \\
33-36 \\
\text { OPX-2 }\end{array}$ & $\begin{array}{l}793 \mathrm{~B} \\
77 \mathrm{R}-3 \\
15-19 \\
\text { OPX-1 }\end{array}$ & $\begin{array}{l}793 \mathrm{~B} \\
77 \mathrm{R}-3 \\
15-19 \\
\text { OPX-2 }\end{array}$ & $\begin{array}{l}793 \mathrm{~B} \\
82 \mathrm{R}-3 \\
75-79 \\
\text { OPX-1 }\end{array}$ \\
\hline \multicolumn{17}{|c|}{ Major elements (wt\%): } \\
\hline $\mathrm{SiO}_{2}$ & 52.72 & 49.91 & 53.86 & 52.27 & 53.67 & 52.54 & 52.75 & 52.98 & 53.02 & 49.97 & 52.91 & 52.69 & 53.37 & 53.36 & 52.54 & 53.05 \\
\hline $\mathrm{TiO}_{2}$ & 0.17 & 0.16 & 0.11 & 0.22 & 0.13 & 0.14 & 0.14 & $\begin{array}{r}32.98 \\
0.16\end{array}$ & $\begin{array}{l}53.02 \\
0.22\end{array}$ & $\begin{array}{r}49.911 \\
0.19\end{array}$ & $\begin{array}{r}32.91 \\
0.22\end{array}$ & $\begin{array}{r}32.09 \\
0.15\end{array}$ & 0.15 & 0.12 & 0.18 & 0.20 \\
\hline $\mathrm{Al}_{2} \mathrm{O}_{3}$ & 1.16 & 0.68 & 1.49 & 1.86 & 1.28 & 1.41 & 0.83 & 1.22 & 0.60 & 1.15 & 1.13 & 1.18 & 1.08 & 0.97 & 1.44 & 1.97 \\
\hline $\mathrm{FeO}$ & 21.80 & 33.49 & 17.23 & 18.90 & 20.37 & 23.02 & 23.15 & 21.72 & 19.98 & 20.42 & 23.26 & 21.52 & 20.55 & 20.63 & 21.16 & 19.00 \\
\hline $\mathrm{MnO}$ & 0.99 & 1.54 & 0.46 & 0.40 & 1.18 & 0.63 & 0.94 & 0.62 & 0.49 & 1.00 & 0.70 & 0.88 & 0.86 & 0.83 & 0.85 & 1.21 \\
\hline $\mathrm{MgO}$ & 21.00 & 10.05 & 24.81 & 22.99 & 21.86 & 20.55 & 20.18 & 21.00 & 23.37 & 20.27 & 20.39 & 21.36 & 22.32 & 22.19 & 21.68 & 23.07 \\
\hline $\mathrm{CaO}$ & 1.68 & 4.24 & 1.83 & 2.00 & 1.53 & 1.84 & 1.67 & 1.89 & 2.18 & 1.72 & 2.07 & 1.71 & 1.74 & 1.62 & 1.80 & 1.10 \\
\hline $\begin{array}{l}\mathrm{Na}_{2} \mathrm{O} \\
\text { Total }\end{array}$ & 99.52 & 100.06 & 99.79 & 98.64 & 100.02 & 100.14 & 99.65 & 99.59 & 99.86 & 94.73 & 100.69 & 99.49 & 100.06 & 99.72 & 99.65 & 99.62 \\
\hline Cations & $0=6$ & & & & & & & & & & & & & & & \\
\hline \multicolumn{17}{|c|}{ Trace elements (ppm): } \\
\hline $\mathrm{Si}$ & 1.978 & 1.995 & 1.967 & 1.951 & 1.987 & 1.968 & 1.988 & 1.982 & 1.967 & 1.969 & 1.974 & 1.975 & 1.978 & 1.984 & 1.963 & 1.960 \\
\hline $\mathrm{Ti}$ & 0.005 & 0.005 & 0.003 & 0.006 & 0.004 & 0.004 & 0.004 & 0.004 & 0.006 & 0.006 & 0.006 & 0.004 & 0.004 & 0.003 & 0.005 & 0.006 \\
\hline $\mathrm{Al}$ & 0.052 & 0.032 & 0.064 & 0.082 & 0.056 & 0.062 & 0.004 & 0.054 & 0.026 & 0.053 & 0.050 & 0.052 & 0.047 & 0.043 & 0.064 & 0.086 \\
\hline $\mathrm{Fe}$ & 0.684 & 1.120 & 0.526 & 0.590 & 0.631 & 0.721 & 0.730 & 0.680 & 0.620 & 0.673 & 0.726 & 0.675 & 0.637 & 0.641 & 0.661 & 0.587 \\
\hline Mn & 0.031 & 0.052 & 0.014 & 0.013 & 0.037 & 0.020 & 0.030 & 0.020 & 0.016 & 0.034 & 0.022 & 0.028 & 0.02 & 0.026 & 0.027 & 0.038 \\
\hline $\mathrm{Mg}$ & 1.174 & 0.599 & 1.351 & 1.279 & 1.206 & 1.148 & 1.134 & 1.171 & 1.292 & 1.191 & 1.134 & 1.193 & 1.28 & 1.230 & 1.208 & 1.271 \\
\hline $\mathrm{Ca}$ & 0.067 & 0.182 & 0.072 & 0.080 & 0.061 & 0.074 & 0.067 & 0.076 & 0.087 & 0.073 & 0.083 & 0.069 & 0.089 & 0.064 & 0.072 & 0.044 \\
\hline $\begin{array}{l}\mathrm{Na} \\
\text { Total }\end{array}$ & 3.991 & 3.984 & 3.998 & 4.002 & 3.981 & 3.997 & 3.990 & 3.987 & 4.014 & 3.998 & 3.995 & 3.995 & 3.995 & 3.991 & 4.000 & 3.991 \\
\hline
\end{tabular}


Table 6. Representative analyses of Ca-rich pyroxenes in forearc samples.

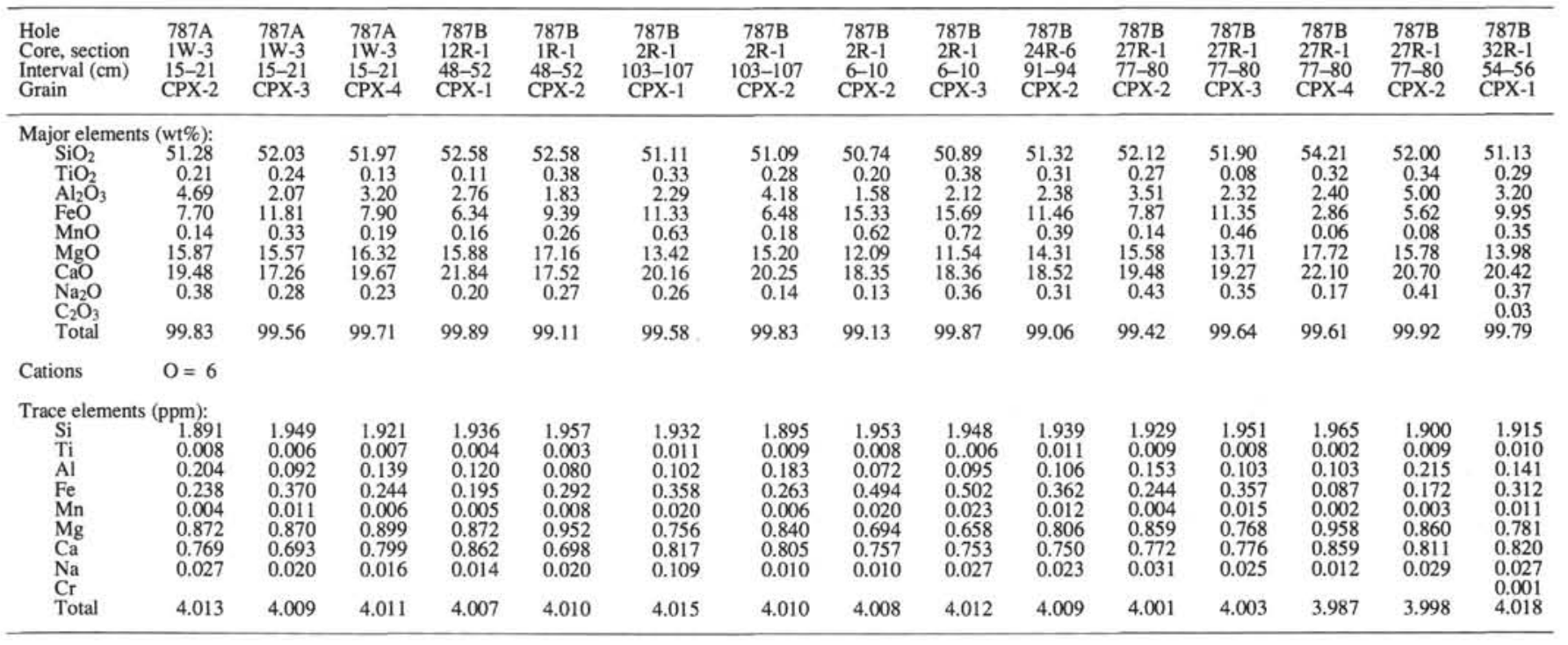

Table 6 (continued).

\begin{tabular}{|c|c|c|c|c|c|c|c|c|c|c|c|c|c|c|c|}
\hline $\begin{array}{l}\text { Hole } \\
\text { Core, section } \\
\text { Interval }(\mathrm{cm}) \\
\text { Grain }\end{array}$ & $\begin{array}{l}793 \mathrm{~B} \\
16 \mathrm{R}-2 \\
83-86 \\
\mathrm{CPX}-4\end{array}$ & $\begin{array}{l}793 \mathrm{~B} \\
22 \mathrm{R}-3 \\
33-36 \\
\text { CPX-2 }\end{array}$ & $\begin{array}{c}793 \mathrm{~B} \\
57 \mathrm{R}-2 \\
139-143 \\
\mathrm{CPX}-1\end{array}$ & $\begin{array}{c}793 \mathrm{~B} \\
57 \mathrm{R}-2 \\
139-143 \\
\mathrm{CPX}-2\end{array}$ & $\begin{array}{c}793 \mathrm{~B} \\
57 \mathrm{R}-2 \\
139-143 \\
\mathrm{CPX}-3\end{array}$ & $\begin{array}{c}793 \mathrm{~B} \\
57 \mathrm{R}-2 \\
139-143 \\
\text { CPX-5 }\end{array}$ & $\begin{array}{c}793 \mathrm{~B} \\
57 \mathrm{R}-2 \\
139-143 \\
\mathrm{CPX}-6\end{array}$ & $\begin{array}{l}793 \mathrm{~B} \\
77 \mathrm{R}-3 \\
15-19 \\
\mathrm{CPX}-2\end{array}$ & $\begin{array}{l}793 \mathrm{~B} \\
77 \mathrm{R}-3 \\
15-19 \\
\mathrm{CPX}-3\end{array}$ & $\begin{array}{l}793 \mathrm{~B} \\
77 \mathrm{R}-3 \\
15-19 \\
\mathrm{CPX}-4\end{array}$ & $\begin{array}{l}793 \mathrm{~B} \\
77 \mathrm{R}-3 \\
15-19 \\
\text { CPX-5 }\end{array}$ & $\begin{array}{l}793 \mathrm{~B} \\
82 \mathrm{R}-3 \\
75-79 \\
\text { CPX-1 }\end{array}$ & $\begin{array}{l}793 \mathrm{~B} \\
82 \mathrm{R}-3 \\
75-79 \\
\text { CPX-2 }\end{array}$ & $\begin{array}{l}793 \mathrm{~B} \\
82 \mathrm{R}-3 \\
75-79 \\
\mathrm{CPX}-4\end{array}$ & $\begin{array}{l}793 \mathrm{~B} \\
82 \mathrm{R}-3 \\
75-79 \\
\text { CPX-5 }\end{array}$ \\
\hline \multicolumn{16}{|c|}{ Major elements (wt\%): } \\
\hline $\begin{array}{l}\mathrm{SiO}_{2} \\
\mathrm{TiO}_{2} \\
\mathrm{Al}_{2} \mathrm{O}_{3} \\
\mathrm{FeO} \\
\mathrm{MnO} \\
\mathrm{MgO} \\
\mathrm{CaO} \\
\mathrm{Na} 2 \\
\mathrm{C}_{2} \mathrm{O}_{3}\end{array}$ & $\begin{array}{r}53.18 \\
0.20 \\
2.18 \\
9.04 \\
0.37 \\
14.72 \\
19.97 \\
0.25\end{array}$ & $\begin{array}{r}51.46 \\
0.31 \\
3.91 \\
9.30 \\
0.29 \\
14.14 \\
21.03 \\
0.23\end{array}$ & $\begin{array}{r}52.34 \\
0.33 \\
2.85 \\
8.85 \\
0.40 \\
14.81 \\
20.25 \\
0.54\end{array}$ & $\begin{array}{r}52.69 \\
0.16 \\
2.69 \\
8.44 \\
0.18 \\
16.40 \\
18.62 \\
0.53\end{array}$ & $\begin{array}{r}52.90 \\
0.21 \\
2.77 \\
8.79 \\
0.21 \\
17.94 \\
16.45 \\
0.40\end{array}$ & $\begin{array}{r}53.51 \\
0.06 \\
2.46 \\
4.16 \\
0.08 \\
17.11 \\
21.84 \\
0.43\end{array}$ & $\begin{array}{r}51.53 \\
0.19 \\
2.79 \\
9.27 \\
0.26 \\
15.70 \\
19.30 \\
0.29\end{array}$ & $\begin{array}{r}51.76 \\
0.23 \\
2.00 \\
10.83 \\
0.48 \\
14.31 \\
19.55 \\
0.40\end{array}$ & $\begin{array}{r}51.47 \\
0.23 \\
2.45 \\
12.14 \\
0.58 \\
13.85 \\
18.75 \\
0.28\end{array}$ & $\begin{array}{r}51.76 \\
0.28 \\
2.24 \\
10.22 \\
0.52 \\
13.90 \\
20.34 \\
0.32\end{array}$ & $\begin{array}{r}50.85 \\
0.35 \\
4.20 \\
8.82 \\
0.23 \\
13.98 \\
21.23 \\
0.23\end{array}$ & $\begin{array}{r}51.39 \\
0.24 \\
2.26 \\
10.98 \\
0.51 \\
14.30 \\
19.43 \\
0.19\end{array}$ & $\begin{array}{r}51.18 \\
0.40 \\
3.14 \\
11.22 \\
0.32 \\
14.11 \\
19.22 \\
0.33\end{array}$ & $\begin{array}{r}52.79 \\
0.13 \\
1.73 \\
9.84 \\
0.43 \\
14.05 \\
21.34 \\
0.36\end{array}$ & $\begin{array}{r}51.99 \\
0.23 \\
1.97 \\
10.87 \\
0.50 \\
14.01 \\
19.93 \\
0.36\end{array}$ \\
\hline Total & 99.92 & 100.68 & 100.37 & 99.72 & 99.66 & 99.66 & 99.32 & 99.56 & 99.73 & 99.57 & 99.90 & 99.31 & 99.91 & 100.68 & 99.86 \\
\hline Cations & $\mathrm{O}=6$ & & & & & & & & & & & & & & \\
\hline $\begin{array}{l}\text { Trace elements } \\
\mathrm{Si}_{\mathrm{Ti}}\end{array}$ & $\begin{array}{r}(\mathrm{ppm}): \\
1.970 \\
0.006 \\
0.095 \\
0.280 \\
0.012 \\
0.813 \\
0.793 \\
0.018\end{array}$ & $\begin{array}{l}1.904 \\
0.009 \\
0.171 \\
0.288 \\
0.009 \\
0.780 \\
0.834 \\
0.018\end{array}$ & $\begin{array}{l}.936 \\
0.009 \\
0.124 \\
0.274 \\
0.013 \\
0.817 \\
0.802 \\
0.039\end{array}$ & $\begin{array}{l}0.261 \\
0.006 \\
0.903 \\
0.736 \\
0.038\end{array}$ & $\begin{array}{l}0.120 \\
0.270 \\
0.007 \\
0.982 \\
0.648 \\
0.026\end{array}$ & $\begin{array}{l}0.106 \\
0.127 \\
0.003 \\
0.931 \\
0.854 \\
0.031\end{array}$ & $\begin{array}{l}0.123 \\
0.290 \\
0.008 \\
0.875 \\
0.773 \\
0.021\end{array}$ & $\begin{array}{l}1.947 \\
0.007 \\
0.089 \\
0.341 \\
0.015 \\
0.802 \\
0.788 \\
0.029\end{array}$ & $\begin{array}{l}1.939 \\
0.007 \\
0.109 \\
0.383 \\
0.018 \\
0.778 \\
0.757 \\
0.021\end{array}$ & $\begin{array}{l}1.945 \\
0.008 \\
0.099 \\
0.321 \\
0.017 \\
0.778 \\
0.819 \\
0.023\end{array}$ & $\begin{array}{l}1.895 \\
0.010 \\
0.184 \\
0.275 \\
0.007 \\
0.776 \\
0.848 \\
0.017\end{array}$ & $\begin{array}{l}1.938 \\
0.007 \\
0.101 \\
0.347 \\
0.016 \\
0.804 \\
0.785 \\
0.014\end{array}$ & $\begin{array}{l}1.918 \\
0.011 \\
0.139 \\
0.352 \\
0.010 \\
0.788 \\
0.772 \\
0.024\end{array}$ & $\begin{array}{l}1.960 \\
0.004 \\
0.076 \\
0.306 \\
0.014 \\
0.778 \\
0.849 \\
0.026\end{array}$ & $\begin{array}{l}1.951 \\
0.007 \\
0.087 \\
0.341 \\
0.016 \\
0.783 \\
0.801 \\
0.026\end{array}$ \\
\hline Total & 3.986 & 4.010 & 4.013 & 4.011 & 4.005 & 4.007 & 4.019 & 4.017 & 4.010 & 4.010 & 4.012 & 4.013 & 4.014 & 4.011 & 4.012 \\
\hline
\end{tabular}


Table 6 (continued).

\begin{tabular}{|c|c|c|c|c|c|c|c|c|c|c|c|c|c|c|c|}
\hline $\begin{array}{l}\text { Hole } \\
\text { Core, section } \\
\text { Interval }(\mathrm{cm}) \\
\text { Grain }\end{array}$ & $\begin{array}{l}792 \mathrm{E} \\
38 \mathrm{R}-5 \\
50-54 \\
\text { CPX-5 }\end{array}$ & $\begin{array}{l}792 \mathrm{E} \\
42 \mathrm{R}-1 \\
76-79 \\
\text { CPX-1 }\end{array}$ & $\begin{array}{l}792 \mathrm{E} \\
42 \mathrm{R}-1 \\
76-79 \\
\text { CPX-2 }\end{array}$ & $\begin{array}{l}792 \mathrm{E} \\
42 \mathrm{R}-1 \\
76-79 \\
\text { CPX-4 }\end{array}$ & $\begin{array}{c}792 \mathrm{E}-5 \\
56 \mathrm{R} \\
33-36 \\
\mathrm{CPX}-1\end{array}$ & $\begin{array}{l}792 \mathrm{E} \\
56 \mathrm{R}-5 \\
33-36 \\
\text { CPX-2 }\end{array}$ & $\begin{array}{l}793 \mathrm{~A} \\
6 \mathrm{H}-3 \\
44-48 \\
\mathrm{CPX}-1\end{array}$ & $\begin{array}{l}793 \mathrm{~A} \\
6 \mathrm{H}-3 \\
44-48 \\
\mathrm{CPX}-2\end{array}$ & $\begin{array}{l}793 \mathrm{~A} \\
6 \mathrm{H}-3 \\
44-48 \\
\text { CPX-4 }\end{array}$ & $\begin{array}{l}793 \mathrm{~A} \\
6 \mathrm{H}-3 \\
44-48 \\
\text { CPX-5 }\end{array}$ & $\begin{array}{l}793 \mathrm{~A} \\
7 \mathrm{H}-1 \\
94-98 \\
\text { CPX-1 }\end{array}$ & $\begin{array}{c}793 \mathrm{~A} \\
9 \mathrm{H}-2 \\
111-114 \\
\text { CPX-2 }\end{array}$ & $\begin{array}{l}\text { 793B } \\
16 \mathrm{R}-2 \\
83-86 \\
\text { CPX-1 }\end{array}$ & $\begin{array}{l}\text { 793B } \\
16 \mathrm{R}-2 \\
83-86 \\
\text { CPX-2 }\end{array}$ & $\begin{array}{l}793 \mathrm{~B} \\
16 \mathrm{R}-2 \\
83-86 \\
\text { CPX-3 }\end{array}$ \\
\hline \multicolumn{16}{|c|}{ Major elements (wt\%): } \\
\hline $\mathrm{SiO}_{2}$ & 53.32 & 52.98 & 52.03 & 53.18 & 53.23 & 52.38 & 52.13 & 51.54 & 51.58 & 53.76 & 52.54 & 51.42 & 53.56 & 53.41 & 52.96 \\
\hline $\mathrm{TiO}_{2}$ & 0.08 & 0.011 & 0.31 & 0.10 & 0.17 & 0.30 & 0.23 & 0.29 & 0.37 & 0.04 & 0.21 & 0.30 & 0.16 & 0.21 & 0.25 \\
\hline $\mathrm{Al}_{2} \mathrm{O}_{3}$ & 2.30 & 2.84 & 3.35 & 2.77 & 1.74 & 3.01 & 1.66 & 2.13 & 2.11 & 1.91 & 2.23 & 1.84 & 1.62 & 2.06 & 2.20 \\
\hline $\mathrm{FeO}$ & 3.90 & 4.06 & 6.30 & 3.44 & 10.18 & 8.16 & 11.90 & 13.48 & 11.74 & 3.69 & 10.16 & 14.99 & 8.93 & 9.69 & 9.54 \\
\hline $\mathrm{MnO}$ & 0.12 & 0.11 & 0.14 & 0.09 & 0.38 & 0.17 & 0.46 & 0.34 & 0.32 & 0.13 & 0.32 & 0.54 & 0.47 & 0.27 & 0.43 \\
\hline $\mathrm{MgO}$ & 16.84 & 15.45 & 16.06 & 17.02 & 14.21 & 15.47 & 13.38 & 13.72 & 13.82 & 17.00 & 16.45 & 12.25 & 14.83 & 14.15 & 14.25 \\
\hline $\mathrm{CaO}$ & 22.91 & 22.88 & 20.80 & 23.06 & 19.15 & 19.85 & 19.85 & 18.21 & 19.28 & 22.95 & 17.25 & 18.48 & 20.05 & 19.80 & 19.76 \\
\hline $\begin{array}{l}\mathrm{Na}_{2} \mathrm{O} \\
\mathrm{C}_{2} \mathrm{O}_{3}\end{array}$ & 0.32 & 0.31 & 0.53 & 0.43 & 0.54 & 0.29 & 0.26 & 0.23 & 0.46 & 0.20 & 0.26 & 0.14 & 0.24 & 0.41 & 0.37 \\
\hline Total & 99.77 & 99.74 & 99.52 & 100.08 & 99.60 & 99.63 & 99.91 & 99.94 & 99.69 & 99.67 & 99.42 & 99.96 & 99.86 & 100.00 & 99.74 \\
\hline Cations & $\mathrm{O}=6$ & & & & & & & & & & & & & & \\
\hline \multicolumn{16}{|c|}{ Trace elements (ppm): } \\
\hline $\mathrm{Si}$ & 1.949 & 1.939 & 1.920 & 1.936 & 1.986 & 1.939 & 1.963 & 1.945 & 1.944 & 1.964 & 1.954 & 1.956 & 1.985 & 1.980 & 1.970 \\
\hline $\mathrm{Ti}$ & 0.002 & 0.003 & 0.009 & 0.003 & 0.005 & 0.008 & 0.007 & 0.008 & 0.011 & 0.001 & 0.006 & 0.009 & 0.004 & 0.006 & 0.007 \\
\hline Al & 0.099 & 0.122 & 0.146 & 0.119 & 0.076 & 0.131 & 0.074 & 0.095 & 0.094 & 0.082 & 0.098 & 0.083 & 0.071 & 0.090 & 0.097 \\
\hline $\mathrm{Fe}$ & 0.119 & 0.124 & 0.194 & 0.105 & 0.318 & 0.253 & 0.376 & 0.425 & 0.370 & 0.113 & 0.316 & 0.477 & 0.277 & 0.301 & 0.297 \\
\hline Mn & 0.004 & 0.004 & 0.005 & 0.003 & 0.012 & 0.006 & 0.015 & 0.011 & 0.010 & 0.004 & 0.010 & 0.017 & 0.015 & 0.009 & 0.013 \\
\hline $\mathrm{Mg}$ & 0.918 & 0.897 & 0.883 & 0.924 & 0.790 & 0.853 & 0.751 & 0.772 & 0.776 & 0.926 & 0.912 & 0.695 & 0.819 & 0.782 & 0.790 \\
\hline $\mathrm{Ca}$ & 0.898 & 0.897 & 0.823 & 0.899 & 0.765 & 0.787 & 0.801 & 0.736 & 0.778 & 0.898 & 0.687 & 0.753 & 0.796 & 0.787 & 0.788 \\
\hline $\mathrm{Na}$ & 0.023 & 0.022 & 0.038 & 0.030 & 0.039 & 0.021 & 0.019 & 0.017 & 0.034 & 0.015 & 0.019 & 0.010 & 0.017 & 0.030 & 0.027 \\
\hline Total & 4.010 & 4.008 & 4.017 & 4.018 & 3.991 & 3.998 & 4.004 & 4.008 & 4.016 & 4.002 & 4.001 & 3.999 & 3.984 & 3.984 & 3.988 \\
\hline
\end{tabular}

Table 6 (continued).

\begin{tabular}{|c|c|c|c|c|c|c|c|c|c|c|c|c|c|c|c|c|}
\hline $\begin{array}{l}\text { Hole } \\
\text { Core, section } \\
\text { Interval (cm) } \\
\text { Grain }\end{array}$ & $\begin{array}{l}792 \mathrm{~A} \\
10 \mathrm{H}-4 \\
73-76 \\
\mathrm{CPX}-2\end{array}$ & $\begin{array}{l}792 \mathrm{~A} \\
10 \mathrm{H}-4 \\
73-76 \\
\mathrm{CPX}-3\end{array}$ & $\begin{array}{l}792 \mathrm{~A} \\
10 \mathrm{H}-4 \\
73-76 \\
\mathrm{CPX}-2\end{array}$ & $\begin{array}{c}792 \mathrm{~B} \\
2 \mathrm{H}-3 \\
145-148 \\
\mathrm{CPX}-4\end{array}$ & $\begin{array}{c}792 \mathrm{~B} \\
2 \mathrm{H}-3 \\
145-148 \\
\mathrm{CPX}-1\end{array}$ & $\begin{array}{c}792 \mathrm{E} \\
9 \mathrm{R}-5 \\
26-31 \\
\mathrm{CPX}-2\end{array}$ & $\begin{array}{c}792 \mathrm{E} \\
9 \mathrm{R}-5 \\
26-31 \\
\mathrm{CPX}-2\end{array}$ & $\begin{array}{l}792 \mathrm{E} \\
9 \mathrm{R}-5 \\
26-31 \\
\mathrm{CPX}-3\end{array}$ & $\begin{array}{l}792 \mathrm{E} \\
9 \mathrm{R}-5 \\
26-31 \\
\mathrm{CPX}-4\end{array}$ & $\begin{array}{c}792 \mathrm{E} \\
12 \mathrm{R}-3 \\
108-111 \\
\mathrm{CPX}-2\end{array}$ & $\begin{array}{c}792 \mathrm{E} \\
12 \mathrm{R}-3 \\
108-111 \\
\mathrm{CPX}-3\end{array}$ & $\begin{array}{c}792 \mathrm{E} \\
12 \mathrm{R}-3 \\
108-111 \\
\mathrm{CPX}-4\end{array}$ & $\begin{array}{l}792 \mathrm{E} \\
14 \mathrm{R}-\mathrm{CC} \\
19-23 \\
\mathrm{CPX}-1\end{array}$ & $\begin{array}{l}792 \mathrm{E} \\
17 \mathrm{R}-2 \\
46-50 \\
\text { CPX-1 }\end{array}$ & $\begin{array}{l}792 \mathrm{E} \\
36 \mathrm{R}-5 \\
50-54 \\
\text { CPX-1 }\end{array}$ & $\begin{array}{l}792 \mathrm{E} \\
38 \mathrm{R}-5 \\
50-54 \\
\text { CPX-4 }\end{array}$ \\
\hline \multicolumn{17}{|c|}{ Major elements (wt\%): } \\
\hline $\mathrm{SiO}_{2}$ & 52.04 & 50.97 & 51.89 & 51.41 & 50.60 & 52.27 & 52.39 & 51.56 & 52.51 & 52.00 & 53.06 & 52.67 & 52.65 & 50.86 & 51.65 & 52.54 \\
\hline $\mathrm{TiO}_{2}$ & 0.44 & 0.41 & 0.66 & 0.40 & 0.28 & 0.22 & 0.17 & 0.12 & 0.12 & 0.18 & 0.10 & 0.11 & 0.10 & 0.59 & 0.41 & 0.18 \\
\hline $\mathrm{Al}_{2} \mathrm{O}_{3}$ & 2.81 & 2.02 & 3.91 & 2.59 & 1.35 & 2.54 & 2.66 & 2.86 & 2.10 & 3.18 & 2.76 & 2.92 & 2.60 & 3.43 & 2.49 & 1.68 \\
\hline $\mathrm{FeO}$ & 7.56 & 8.50 & 8.64 & 10.99 & 21.55 & 8.16 & 7.52 & 7.82 & 6.75 & 6.52 & 5.01 & 4.84 & 6.37 & 9.26 & 10.47 & 9.48 \\
\hline $\mathrm{MnO}$ & 0.23 & 0.22 & 0.17 & 0.37 & 0.94 & 0.16 & 0.20 & 0.18 & 0.20 & 0.15 & 0.16 & 0.16 & 0.10 & 0.29 & 0.30 & 0.81 \\
\hline $\mathrm{MgO}$ & 16.10 & 15.68 & 15.01 & 14.08 & 10.01 & 15.84 & 16.87 & 15.34 & 16.84 & 16.55 & 16.89 & 16.44 & 15.96 & 14.63 & 14.62 & 14.07 \\
\hline $\mathrm{CaO}$ & 20.10 & 18.67 & 20.28 & 19.84 & 16.06 & 20.35 & 19.22 & 21.06 & 20.33 & 20.46 & 21.53 & 22.25 & 21.58 & 20.49 & 19.78 & 20.79 \\
\hline $\mathrm{Na}_{2} \mathrm{O}$ & 0.28 & 0.24 & 0.30 & 0.32 & 0.14 & 0.22 & 0.45 & 0.24 & 0.33 & 0.34 & 0.34 & 0.23 & 0.13 & 0.25 & 0.35 & 0.23 \\
\hline Total & 99.58 & 96.69 & 100.85 & 99.99 & 100.93 & 99.75 & 99.48 & 99.17 & 99.18 & 99.39 & 99.85 & 99.62 & 99.50 & 99.81 & 100.09 & 99.78 \\
\hline Cations & $\mathrm{O}=6$ & & & & & & & & & & & & & & & \\
\hline \multicolumn{17}{|c|}{ Trace elements (ppm): } \\
\hline $\mathrm{Si}$ & 1.927 & 1.948 & 1.905 & 1.927 & 1.958 & 1.937 & 1.936 & 1.925 & 1.946 & 1.921 & 1.941 & 1.934 & 1.944 & 1.899 & 1.929 & 1.965 \\
\hline $\mathrm{Ti}$ & 0.012 & 0.012 & 0.018 & 0.011 & 0.008 & 0.006 & 0.005 & 0.003 & 0.003 & 0.005 & 0.003 & 0.003 & 0.003 & 0.016 & 0.012 & 0.005 \\
\hline Äl & 0.023 & 0.091 & 0.169 & 0.144 & 0.061 & 0.111 & 0.116 & 0.126 & 0.092 & 0.139 & 0.119 & 0.126 & 0.113 & 0.151 & 0.110 & 0.074 \\
\hline $\mathrm{Fe}$ & 0.235 & 0.272 & 0.265 & 0.345 & 0.697 & 0.253 & 0.232 & 0.244 & 0.209 & 0.201 & 0.153 & 0.149 & 0.197 & 0.289 & 0.327 & 0.296 \\
\hline Mn & 0.007 & 0.007 & 0.005 & 0.012 & 0.031 & 0.005 & 0.006 & 0.006 & 0.006 & 0.005 & 0.005 & 0.005 & 0.003 & 0.009 & 0.009 & 0.026 \\
\hline $\mathrm{Mg}$ & 0.889 & 0.893 & 0.821 & 0.787 & 0.577 & 0.875 & 0.929 & 0.854 & 0.930 & 0.911 & 0.921 & 0.900 & 0.879 & 0.815 & 0.814 & 0.784 \\
\hline $\mathrm{Ca}$ & 0.797 & 0.764 & 0.753 & 0.797 & 0.666 & 0.808 & 0.761 & 0.842 & 0.807 & 0.810 & 0.844 & 0.875 & 0.854 & 0.820 & 0.791 & 0.833 \\
\hline $\mathrm{Na}$ & 0.021 & 0.018 & 0.022 & 0.023 & 0.010 & 0.016 & 0.032 & 0.017 & 0.024 & 0.025 & 0.024 & 0.017 & 0.010 & 0.018 & 0.025 & 0.017 \\
\hline Total & 4.010 & 4.004 & 4.003 & 4.016 & 4.009 & 4.010 & 4.018 & 4.017 & 4.017 & 4.017 & 4.009 & 4.008 & 4.001 & 4.018 & 4.017 & 4.001 \\
\hline
\end{tabular}


Table 6 (continued).

\begin{tabular}{|c|c|c|c|c|c|c|}
\hline $\begin{array}{l}\text { Hole } \\
\text { Core, section } \\
\text { Interval }(\mathrm{cm}) \\
\text { Grain }\end{array}$ & $\begin{array}{c}793 \mathrm{~B} \\
89 \mathrm{R}-1 \\
128-132 \\
\text { CPX-1 }\end{array}$ & $\begin{array}{c}793 \mathrm{~B} \\
89 \mathrm{R}-1 \\
128-132 \\
\mathrm{CPX}-2\end{array}$ & $\begin{array}{c}793 \mathrm{~B} \\
89 \mathrm{R}-1 \\
128-132 \\
\text { CPX-3 }\end{array}$ & $\begin{array}{c}793 \mathrm{~B} \\
89 \mathrm{R}-1 \\
128-132 \\
\mathrm{CPX}-4\end{array}$ & $\begin{array}{c}793 \mathrm{~B} \\
89 \mathrm{R}-1 \\
128-132 \\
\mathrm{CPX}-5\end{array}$ & $\begin{array}{c}793 \mathrm{~B} \\
89 \mathrm{R}-1 \\
128-132 \\
\text { CPX-6 }\end{array}$ \\
\hline \multicolumn{7}{|c|}{ Major elements (wt\%): } \\
\hline $\mathrm{SiO}_{2}$ & 52.54 & 52.82 & 52.81 & 52.20 & 52.78 & 52.11 \\
\hline $\mathrm{TiO}_{2}$ & 0.11 & 0.14 & 0.15 & 0.14 & 0.10 & 0.13 \\
\hline $\mathrm{Al}_{2} \mathrm{O}_{3}$ & 2.27 & 2.05 & 2.35 & 2.44 & 2.31 & 2.40 \\
\hline $\mathrm{FeO}$ & 8.43 & 8.60 & 8.39 & 8.79 & 8.16 & 8.36 \\
\hline $\mathrm{MnO}$ & 0.18 & 0.23 & 0.18 & 0.23 & 0.17 & 0.13 \\
\hline $\mathrm{MgO}$ & 15.78 & 15.84 & 15.74 & 15.15 & 15.91 & 15.63 \\
\hline $\mathrm{CaO}$ & 19.83 & 19.74 & 19.92 & 20.33 & 20.06 & 19.46 \\
\hline $\begin{array}{l}\mathrm{Na}_{2} \mathrm{O} \\
\mathrm{C}_{2} \mathrm{O}_{3}\end{array}$ & 0.58 & 0.29 & 0.27 & 0.42 & 0.37 & 0.47 \\
\hline Total & 99.73 & 99.70 & 99.82 & 99.68 & 99.85 & 98.74 \\
\hline Cations & $O=6$ & & & & & \\
\hline \multicolumn{7}{|c|}{ Trace elements (ppm): } \\
\hline $\mathrm{Si}$ & 1.949 & 1.958 & 1.953 & 1.943 & 1.951 & 1.949 \\
\hline $\mathrm{Ti}$ & 0.003 & 0.004 & 0.004 & 0.004 & 0.003 & 0.004 \\
\hline Al & 0.099 & 0.090 & 0.103 & 0.107 & 0.101 & 0.106 \\
\hline $\mathrm{Fe}$ & 0.261 & 0.267 & 0.259 & 0.274 & 0.252 & 0.262 \\
\hline $\mathrm{Mn}$ & 0.006 & 0.007 & 0.006 & 0.007 & 0.005 & 0.006 \\
\hline $\mathrm{Mg}$ & 0.872 & 0.875 & 0.867 & 0.840 & 0.877 & 0.871 \\
\hline $\mathrm{Ca}$ & 0.788 & 0.784 & 0.789 & 0.811 & 0.795 & 0.780 \\
\hline $\mathrm{Na}$ & 0.042 & 0.021 & 0.020 & 0.030 & 0.027 & 0.03 \\
\hline $\begin{array}{l}\mathrm{Cr} \\
\text { Total }\end{array}$ & 4.020 & 4.004 & 4.001 & 4.015 & 4.009 & 4.011 \\
\hline
\end{tabular}

Table 7. Representative analyses of hornblendes in forearc samples.

\begin{tabular}{|c|c|c|c|c|}
\hline $\begin{array}{l}\text { Hole } \\
\text { Core, section } \\
\text { Interval }(\mathrm{cm}) \\
\text { Grain }\end{array}$ & $\begin{array}{c}792 \mathrm{E} \\
56 \mathrm{R}-5 \\
33-36 \\
\text { AMP-1 }\end{array}$ & $\begin{array}{c}792 \mathrm{E} \\
56 \mathrm{R}-5 \\
33-36 \\
\text { AMP-2 }\end{array}$ & $\begin{array}{c}792 \mathrm{E} \\
56 \mathrm{R}-5 \\
33-36 \\
\text { AMP-3 }\end{array}$ & $\begin{array}{c}792 \mathrm{E} \\
56 \mathrm{R}-5 \\
33-36 \\
\text { AMP-4 }\end{array}$ \\
\hline $\begin{array}{l}\text { Major element } \\
\mathrm{SiO}_{2} \\
\mathrm{TiO}_{2} \\
\mathrm{Al}_{2} \mathrm{O}_{3} \\
\mathrm{FeO} \\
\mathrm{MnO} \\
\mathrm{MgO} \\
\mathrm{CaO} \\
\mathrm{Na}_{2} \mathrm{O} \\
\mathrm{K}_{2} \mathrm{O} \\
\text { Total }\end{array}$ & $\begin{array}{r}\text { (wt\%): } \\
50.08 \\
1.12 \\
8.01 \\
12.39 \\
0.51 \\
15.30 \\
11.21 \\
1.18 \\
0.08 \\
99.89\end{array}$ & $\begin{array}{r}50.51 \\
1.18 \\
7.34 \\
12.95 \\
0.53 \\
15.14 \\
11.27 \\
1.24 \\
0.15 \\
100.30\end{array}$ & $\begin{array}{r}49.26 \\
1.38 \\
8.25 \\
13.03 \\
0.55 \\
14.81 \\
11.24 \\
1.73 \\
0.14 \\
100.37\end{array}$ & $\begin{array}{r}49.86 \\
1.30 \\
7.58 \\
12.78 \\
0.54 \\
15.06 \\
12.16 \\
1.46 \\
0.05 \\
100.79\end{array}$ \\
\hline Cations & $\mathrm{O}=23$ & & & \\
\hline $\begin{array}{c}\text { Trace element } \\
\mathrm{Si} \\
\mathrm{Ti} \\
\mathrm{Al} \\
\mathrm{Fe} \\
\mathrm{Mn} \\
\mathrm{Mg} \\
\mathrm{Ca} \\
\mathrm{Na} \\
\mathrm{K} \\
\text { Total }\end{array}$ & $\begin{array}{r}\text { (ppm): } \\
7.075 \\
0.119 \\
1.333 \\
1.464 \\
0.061 \\
3.221 \\
1.697 \\
0.323 \\
0.015 \\
15.309\end{array}$ & $\begin{array}{r}7.128 \\
0.125 \\
1.220 \\
1.528 \\
0.063 \\
3.185 \\
1.704 \\
0.340 \\
0.026 \\
15.319\end{array}$ & $\begin{array}{r}6.976 \\
0.147 \\
1.376 \\
1.543 \\
0.066 \\
3.126 \\
1.706 \\
0.476 \\
0.025 \\
15.439\end{array}$ & $\begin{array}{r}7.030 \\
0.138 \\
1.259 \\
1.507 \\
0.064 \\
3.165 \\
1.837 \\
0.398 \\
0.008 \\
15.406\end{array}$ \\
\hline
\end{tabular}



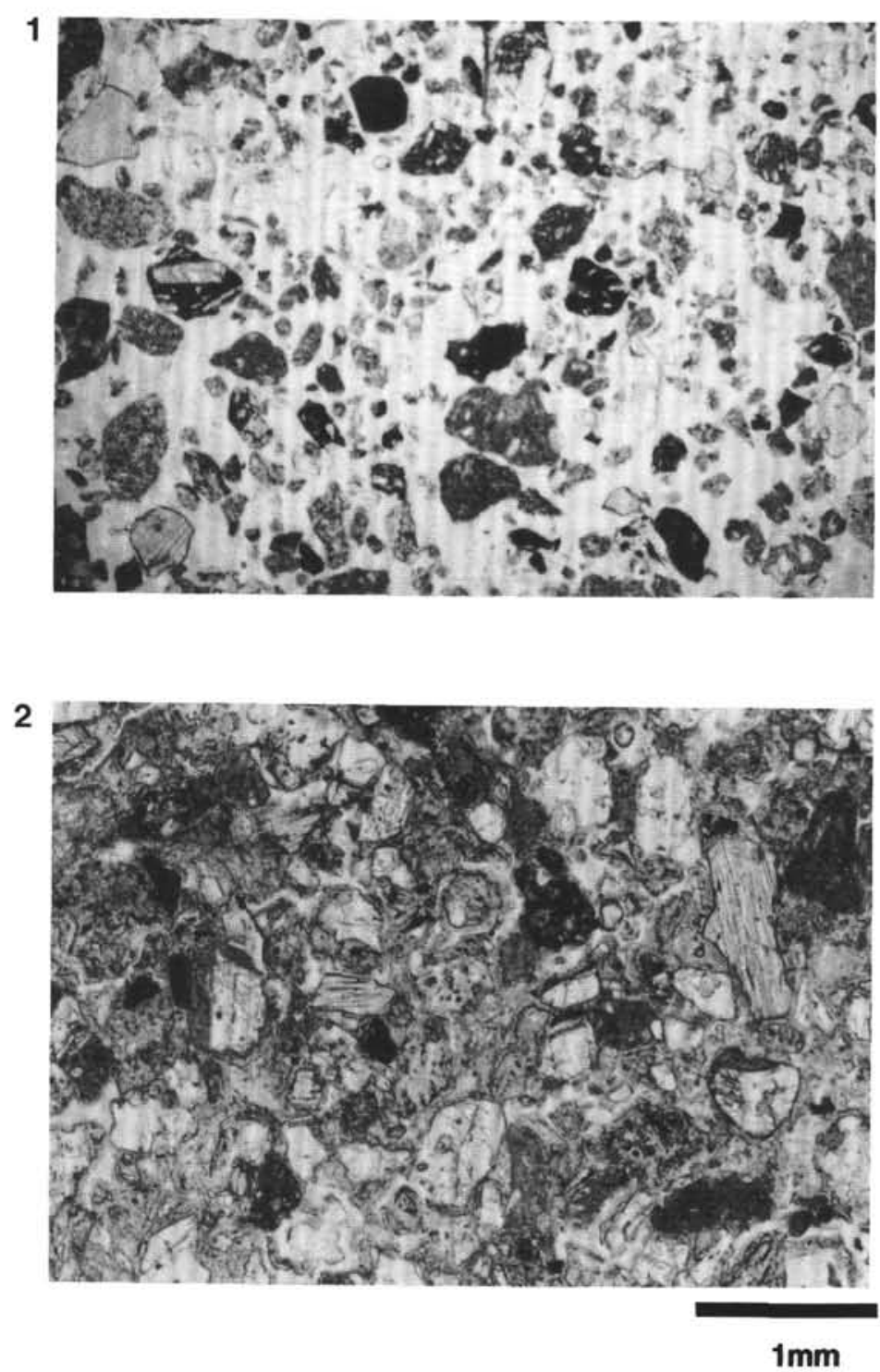

Plate 1. 1.Volcaniclastic sand (Sample 126-792E-9R-5, 26-31 cm) observed in thin section. Scale bar is 1 mm. 2. Volcaniclastic sandstone (Sample $126-792 \mathrm{E}-42 \mathrm{R}-1,76-79 \mathrm{~cm}$ ) observed in thin section. Scale bar is $1 \mathrm{~mm}$. 